
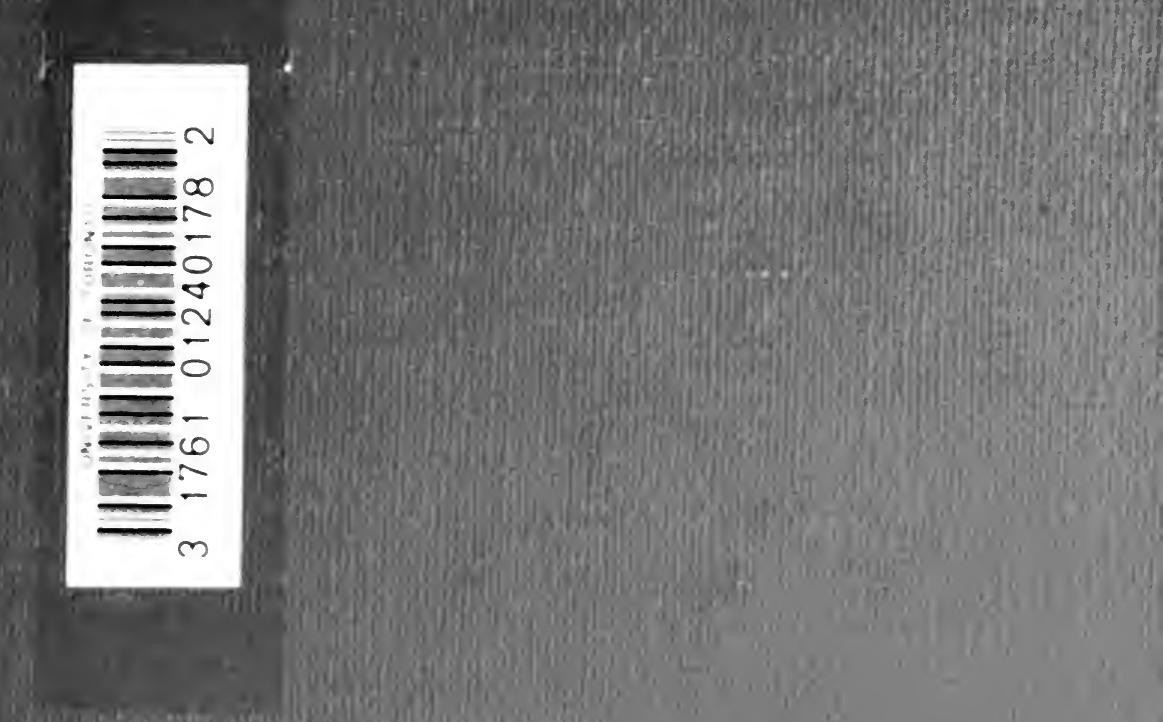



<smiles>CC1CC1</smiles> 


\section{MOMENTS OF VISION}

A. I

MISCELLANEOUS VERSES 


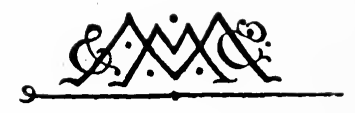

\author{
MACMILLAN AND CO., LIMITED \\ LONDON - BOMBAY - CALCUTTA - MADRAS \\ MELBOURNE' \\ THE MACMILLAN COMPANY \\ NEW YORK - BOSTON - CHICAGO \\ DALLAS - SAN FRANCISCO
}

THE MACMILLAN CO. OF CANADA, LTD. TORONTO 


\title{
MOMENTS OF VISION
} A N D

\section{MISCELLANEOUS VERSES}

\author{
BY \\ THOMAS HARDY
}

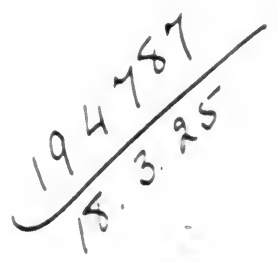

MACMILLAN AND CO, LIMITED ST. MARTIN'S STREET, LONDON 1919 
COPYRIGHT

PR

4750

$M 6$

cop 2 


\section{CONTENTS}

Moments of Vision PAGE

The Voice of Things . $\quad$. $\quad$. 2

"Why be at pains ?" . . . . . . 3

"Wc sat at the window" . . . . . 4

Afternoon Service at Mellstock . . . . 5

At the Wicket-gate . . . . . . . 6

In a Muscum . $\quad$. $\quad$. $\quad$. $\quad$. $\quad$. 7

Apostrophe to an Old Psalm 'Tune . . . 8

At the Word. "Farewell" . . . . I I

First Sight of Her and After . . . . 13

The Rival . . . . . . . 14

Heredity . . . . . . . . . 15

"You were the sort that men forget" . . 16

She, I, and They . . . . . . . 17

Near Lanivet, 1872 . $\quad . \quad$. . . . 18

Joys of Memory . . . . . . 20

To the Moon . . $\quad$. $\quad$. $\quad$. 2 I

Copying Architecture in an Old Minster . . 22 
To Shakespeare . $\quad$. $\quad$. $\quad$. 24

Quid hic agis ? $\quad . \quad$. $\quad . \quad$ • $\quad 27$

On a Midsummer Eve $\quad . \quad$. $\quad . \quad 30$

Timing Her . . . . . . . 31

Before Knowledge • • • • • • 34

The Blinded Bird . $\quad . \quad$. $\quad . \quad 35$

"The wind blew words" . . . . . $3^{6}$

The Faded Face . $\quad . \quad$. $\quad . \quad$. 37

The Riddle . $\quad . \quad$. $\quad . \quad$. $\quad .38$

The Duel . $\quad . \quad$. $\quad . \quad$. 39

At Mayfair Lodgings . $\quad$. $\quad$. $\quad 42$

To my Father's Violin . • • • • 44

The Statue of Liberty $\quad$ • $\quad$ • $\quad$ • 47

The Background and the Figure . . . 50

The Change . $\quad . \quad$. $\quad . \quad$. $5 \mathbf{I}$

Sitting on the Bridge $. \quad . \quad . \quad \cdot 54$

The Young Churchwarden . . . . 56

"I travel as a phantom now" • • • • • 57

Lines to a Movement in Mozart's E-flat Symphony $\quad 5^{8}$

"In the screnties" . . . . . . . 60

The Pedigree . . . . . . . . 62

His Heart. A Woman's Dream . . . 65

Where they lived . . . . . . . 68

The Occultation . $\quad . \quad$. $\quad . \quad$. 69

Life laughs Onward $\quad \cdot \quad \cdot \quad \cdot \quad \cdot 70$

The Peace-offering . $\quad$. $\quad . \quad$. $7 \mathbf{I}$ 


\section{CONTENTS}

"Something tapped"

The Wound . . . . . . . 73

A Merrymaking in Question . . . . 74

"I said and sang her excellence" . . . 75

A January Night. 1879 . . . . . . 77

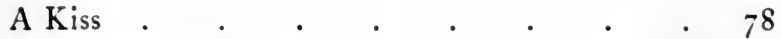

The Announcement . $\quad$ • $\quad$ • $\quad$. 79

The Oxen . . . . . . . 80

The Tresses . . . . . . 8 I

The Photograph . . . . . 82

On a Heath $\quad$. $\quad . \quad$. $\quad . \quad$. 84

An Anniversary . $\quad . \quad$. $\quad . \quad 85$

"By the Runic Stone" • . . . . $\quad 87$

The Pink Frock . . . . . 88

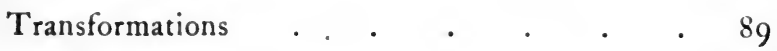

In her Precincts . . . . . . 90

The Last Signal . . . . . . . 9I

The House of Silence . . . . . 93

Great Things . . . . . . . 95

The Chimes $\quad . \quad$. $\quad . \quad$. 97

The Figure in the Scene . • . . . $\quad 9^{8}$

"Why did I sketch" • . . . . . . 99

Conjecture . . . . . . . 100

The Blow . . . . . . . 101

Love the Monopolist . . . . . 103

At Middle-field Gate in February . . . 105 
The Youth who carried a Light . . . 106 The Head above the Fog . . : . . 108

Overlooking the River Stour . • • • 109

The Musical Box . . . . . . . I I I

On Sturminster Foot-bridge . . . . • II3

Royal Sponsors . . . . . . . II4

Old Furniture . $\quad . \quad$. . . . 116

A Thought in Two Moods . . . . 118

The Last Performance . . . . . 119

"You on the tower" . . . . . 120

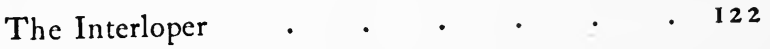

Logs on the Hearth . . . . . 124

The Sunshade. . . . . . . 126

The Ageing House . . . . . . $\quad$. 128

The Caged Goldfinch • • • • • 129

At Madame Tussaud's in Victorian Years . . I30

The Ballet $. \quad . \quad . \quad . \quad . \quad . \quad 132$

The Five Students . $\quad . \quad$. $\quad . \quad$. 133

The Wind's Prophecy . • . . • 135

During Wind and Rain • • • • • • $\quad$ I 37

He prefers her Earthly . • • • • 139

The Dolls . . • . . . $\quad$. 140

Molly gone . . . . . . . 141

A Backward Spring . • . . . . 143

Looking Across . $\quad . \quad$. $\quad . \quad$ I 44

At a Seaside Town in 1869 . . . . 146 


\section{CONTENTS}

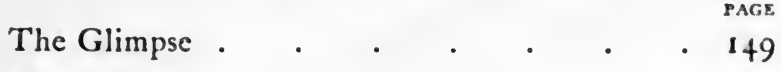

The Pedestrian . . . . . . $15 \mathbf{I}$

"Who's in the next room ?" . . . . 153

At a Country Fair . . . . . . 155

The Memorial Brass : $186-$. . . . 156

Her Love-birds . . . . . . 158

Paying Calls . . . . . . . 160

The Upper Birch-Leares . . . . . 161

"It never looks like summer" . . . . 162

Everything comes . . . . . . 163

The Man with a Past . . . . . $16+$

Hc fears his Good Fortunc . . . . 166

He wonders about Himself . . . . . 167

Jubilate . . . . . . . 168

He revisits his First School . . . . 171

"I thought, my Heart" . . . . . 173

Fragment. $. \quad . \quad . \quad . \quad . \quad 174$

Midnight on the Great Western . . . 176

Honcymoon-time at an Inn . . . 177

The Robin . . . . . . $18 \mathbf{I}$

"I rose and went to Rou'tor 'Town". . . 183

The Nettles . . . . . . . . $\quad$ : $\varepsilon_{4}$

In a Waiting-room . . . . . . 18 ;

The Clock-winder . $\quad . \quad$. $\quad . \quad 187$

Old Excursions $\quad . \quad$ • $\quad . \quad$. $\quad 189$

The Masked Face $\quad . \quad$. $\quad . \quad$. I9I 
In a Whispering Gallery • • • • • $\quad$ - 192

The Something that saved Him . • • 193

The Enemy's Portrait • • • • . 195

Imaginings $\quad \cdot \quad \cdot \quad \cdot \quad \cdot \quad \cdot \quad \cdot \quad \cdot 197$

On the Doorstep $\quad . \quad$ • $\quad . \quad$ • $\quad .198$

Signs and Tokens $\quad . \quad+\quad . \quad+\quad . \quad$. 199

Paths of Former Time . . . . . 201

The Clock of the Years . . . . . 203

At the Piano . . . . . . 205

The Shadow on the Stone . . . 206

In the Garden. . . . . . 208

The Tree and the Lady . . . . . 209

An Upbraiding . . . . . . 211

The Young Glass-stainer • • . • • 212

Looking at a Picture on an Anniversary • • 213

The Choirmaster's Burial . . . . . 215

The Man who forgot . • . . $\quad 217$

While drawing in a Churchyard . . . 219

"For Life I had never cared greatly" . 221

Poems of War and Patriotism-

His Country $\quad$. $\quad$. $\quad$. $\quad 225$

England to Germany in 1914 . . $\quad 227$

On the Belgian Expatriation • • $\quad 228$

An Appeal to America on behalf of the Belgian Destitute . . . $\quad 229$ 
The Pity of It .

- 230

In Time of Wars and 'Iumults . . . 231

In Time of "the Breaking of Nations" . 232

Cry of the Homeless. . . . 233

Before Marching and After : . $\quad 235$

"Often when warring" . . . . 237

Then and Now $\quad . \quad$. $\quad . \quad 238$

A Call to National Service . . . 240

The Dead and the Living Onc . . . 241

A New Year's Eve in War Time . . 244

"I met a man" . . . . . 246

"I looked up from my writing" . . $\quad 24^{8}$

Finale-

The Coming of the End . . . . 253

Afterwards . . . . . . 255 



\section{MOMENTS OF VISION}

\section{That mirror}

Which makes of men a transparency,

Who holds that mirror

And bids us such a breast-bared spectacle see

Of you and me?

That mirror

Whose magic penetrates like a dart,

Who lifts that mirror

And throws our mind back on us, and our heart,

Until we start?

That mirror

Works well in these night hours of ache;

Why in that mirror

Are tincts we never see ourselves once take

When the world is awake?

That mirror

Can test each mortal when unaware ;

Yea, that strange mirror

May catch his last thoughts, whole life foul or fair,

Glassing it-where? 


\section{THE VOICE OF THINGS}

ForTy Augusts-aye, and several more-ago,

When I paced the headlands loosed from dull employ,

The waves huzza'd like a multitude below,

In the sway of an all-including joy

Without cloy.

Blankly I walked there a double decade after,

When thwarts had flung their toils in front of me,

And I heard the waters wagging in a long ironic laughter

At the lot of men, and all the vapoury

Things that be.

Wheeling change has set me again standing where

Once I heard the waves huzza at Lammas-tide ;

But they supplicate now-like a congregation there

Who murmur the Confession-I outside, Prayer denied. 
“WHY BE AT PAINS?"

\section{(Wooer's Song)}

$\mathrm{W}_{\text {HY }}$ be at pains that I should know

You sought not me?

Do breezes, then, make features glow So rosily?

Come, the lit port is at our back, And the tumbling sea;

Elsewhere the lampless uphill track

To uncertainty !

O should not we two waifs join hands?

I am alone,

You would enrich me more than lands

By being my own.

Yet, though this facile moment flies,

Close is your tone,

And ere to-morrow's dewfall drics

I plough the unknown. 
"WE SAT AT THE WINDOW"

\section{(Bournemouth, 1875)}

WE sat at the window looking out, And the rain came down like silken strings That Swithin's day. Each gutter and spout Babbled unchecked in the busy way

Of witless things :

Nothing to read, nothing to see

Seemed in that room for her and me

On Swithin's day.

We were irked by the scene, by our own selves; yes,

For I did not know, nor did she infer

How much there was to read and guess

By her in me, and to see and crown

By me in her.

Wasted were two souls in their prime, And great was the waste, that July time When the rain came down. 


\title{
AFTERNOON SERVICE AT MELLSTOCK
}

\author{
(Circa I 850)
}

ON afternoons of drowsy calm

We stood in the panelled pew,

Singing one-voiced a Tate-and-Brady psalm

To the tune of "Cambridge New."

We watched the elms, we watched the rooks,

The clouds upon the breeze,

Between the whiles of glancing at our books, And swaying like the trees.

So mindless were those outpourings !-

Though I am not aware

That I have gained by subtle thought on things

Since we stood psalming there. 


\section{AT THE WICKET-GATE}

ThERE floated the sounds of church-chiming,

But no one was nigh,

Till there came, as a break in the loneness,

Her father, she, I.

And we slowly moved on to the wicket,

And downlooking stood,

Till anon people passed, and amid them

We parted for good.

Greater, wiser, may part there than we three

Who parted there then,

But never will Fates colder-featured

Hold sway there again.

Of the churchgoers through the still meadows

No single one knew

What a play was played under their eyes there

As thence we withdrew. 


\section{IN A MUSEUM}

Here's the mould of a musical bird long passed from light,

Which over the earth before man came was winging ;

There's a contralto voice I heard last night, That lodges in me still with its sweet singing.

\section{II}

Such a dream is Time that the coo of this ancient bird

Has perished not, but is blent, or will be blending

Mid visionless wilds of space with the voice that I heard,

In the full-fugued song of the universe unending.

EXETER. 


\section{APOSTROPHE TO AN OLD PSALM TUNE}

I MET you first-ah, when did I first meet you ?

When I was full of wonder, and innocent, Standing meek-eyed with those of choric bent,

While dimming day grew dimmer In the pulpit-glimmer.

Much riper in years I met you-in a temple Where summer sunset streamed upon our shapes,

And you spread over me like a gauze that drapes,

And flapped from floor to rafters, Sweet as angels' laughters.

But you had been stripped of some of your old vesture

By Monk, or another. Now you wore no frill, 


\section{TO AN OLD PSALM TUNE}

And at first you startled me. But I knew you still,

Though I missed the minim's waver, And the dotted quaver.

I grew accustomed to you thus. And you hailed me

Through one who evoked you often. Then at last

Your raiser was borne off, and I mourned you had passed

From my life with your late outsetter;

Till I said, "'Tis better!"

But you waylaid me. I rose and went as a ghost goes,

And said, eyes-full : “I'll never hear it again!

It is overmuch for scathed and memoried men

When sitting among strange people

Under their steeple."

Now, a new stirrer of tones calls you up before me

And wakes your speech, as she of Endor did (When sought by Saul who, in disguises hid,

Fell down on the earth to hear it)

Samuel's spirit. 
Io TO AN OLD PSALM TUNE

So, your quired oracles beat till they make me tremble

As I discern your mien in the old attire, Here in these turmoiled years of belligerent fire

Living still on-and onward, maybe,

Till Doom's great day be !

Sunday, August 13, 1916. 


\section{AT THE WORD "FAREWELL"}

SHE looked like a bird from a cloud

On the clammy lawn,

Moving alone, bare-browed

In the dim of dawn,

The candles alight in the room

For my parting meal

Made all things withoutdoors loom

Strange, ghostly, unreal.

The hour itself was a ghost,

And it seemed to me then

As of chances the chance furthermost

I should see her again.

I beheld not where all was so fleet

That a Plan of the past

Which had ruled us from birthtime to meet

Was in working at last :

No prelude did I there perceive

To a drama at all,

Or foreshadow what fortune might weave

From beginnings so small ; 


\section{I2 AT THE WORD "FAREWELL"}

But I rose as if quicked by a spur

I was bound to obey,

And stepped through the casement to her Still alone in the gray.

"I am leaving you. . . . Farewell !" I said, As I followed her on

By an alley bare boughs overspread;

"I soon must be gone!"

Even then the scale might have been turned Against love by a feather,

-But crimson one cheek of hers burned

When we came in together. 


\section{FIRST SIGHT OF HER AND AFTER}

A DAY is drawing to its fall

I had not dreamed to see ;

The first of many to enthrall

My spirit, will it be?

Or is this eve the end of all Such new delight for me?

I journey home : the pattern grows Of moonshades on the way:

"Soon the first quarter, I suppose," Sky-glancing travellers say;

I realize that it, for those,

Has been a common day. 


\section{THE RIVAL}

I DETERMINED to find out whose it wasThe portrait he looked at so, and sighed; Bitterly have I rued my meanness And wept for it since he died!

I searched his desk when he was away, And there was the likeness-yes, my own! Taken when I was the season's fairest, And time-lines all unknown.

I smiled at my image, and put it back, And he went on cherishing it, until I was chafed that he loved not the me then living,

But that past woman still.

Well, such was my jealousy at last, I destroyed that face of the former me ; Could you ever have dreamed the heart of woman

Would work so foolishly ! 


\section{HEREDITY}

I AM the family face;

Flesh perishes, I live on, Projecting trait and trace

Through time to times anon, And leaping from place to place Over oblivion.

The years-heired feature that can In curve and voice and eye

Despise the human span Of durance-that is I ; The eternal thing in man, That heeds no call to die. 
“YOU WERE THE SORT THAT MEN FORGET".

You were the sort that men forget;

Though I-not yet! -

Perhaps not ever. Your slighted weakness

Adds to the strength of my regret!

You'd not the art-you never had

For good or bad-

To make men see how sweet your meaning,

Which, visible, had charmed them glad.

You would, by words inept let fall, Offend them all,

Even if they saw your warm devotion

Would hold your life's blood at their call.

You lacked the eye to understand

Those friends offhand

Whose mode was crude, though whose dim

purport

Outpriced the courtesies of the bland.

I am now the only being who

Remembers you

It may be. What a waste that Nature

Grudged soul so dear the art its due! 


\section{SHE, I, AND THEY}

I was sitting,

She was knitting,

And the portraits of our fore-folk hung around ;

When there struck on us a sigh;

"Ah-what is that?" said I :

"Was it not you ?" said she. "A sigh did sound."

I had not breathed it,

Nor the night-wind heaved it,

And how it came to us we could not guess;

And we looked up at each face

Framed and glazed there in its place,

Stillhearkening; but thenceforth was silentness.

Half in dreaming,

"Then its meaning,"

Said we, "must be surely this; that they repine

That we should be the last

Of stocks once unsurpassed,

And unable to keep up their sturdy line."

1916.

M V

C 


\section{NEAR LANIVET, 1872}

There was a stunted handpost just on the crest,

Only a few feet high :

She was tired, and we stopped in the twilighttime for her rest, At the crossways close thereby.

She leant back, being so weary, against its stem, And laid her arms on its own,

Each open palm stretched out to each end of them,

Her sad face sideways thrown.

Her white-clothed form at this dim-lit cease of day

Made her look as one crucified

In my gaze at her from the midst of the dusty way,

And hurriedly "Don't," I cried.

I do not think she heard. Loosing thence she said, As she stepped forth ready to go, 
"I am rested now.-Something strange came into my head ;

I wish I had not leant so !"

And wordless we moved onward down from the hill

In the west cloud's murked obscure,

And looking back we could see the handpost still

In the solitude of the moor.

"It struck her too," I thought, for as if afraid

She heavily breathed as we trailed;

Till she said, "I did not think how 'twould look in the shade, When I leant there like one nailed."

I, lightly: "There's nothing in it. For you, anyhow!"

— "O I know there is not," said she . .

"Yet I wonder... If no one is bodily crucified now,

In spirit one may be!"

And we dragged on and on, while we seemed to see

In the running of Time's far glass

Her crucified, as she had wondered if she might be

Some day.-Alas, alas ! 


\section{JOYS OF MEMORY}

WHEN the spring comes round, and a certain day

Looks out from the brume by the eastern copsetrees

And says, Remember,

I begin again, as if it were new,

A day of like date I once lived through,

Whiling it hour by hour away;

So shall I do till my December,

When spring comes round.

I take my holiday then and my rest Away from the dun life here about me,

Old hours re-greeting

With the quiet sense that bring they must Such throbs as at first, till I house with dust,

And in the numbness my heartsome zest

For things that were, be past repeating When spring comes round. 


\section{TO THE MOON}

"What have you looked at, Moon, In your time,

Now long past your prime?" “ $O$, I have looked at, often looked at Sweet, sublime,

Sore things, shudderful, night and noon In my time."

"What have you mused on, Moon, In your day,

So aloof, so far away?"

" $\mathrm{O}$, I have mused on, often mused on Growth, decay,

Nations alive, dead, mad, aswoon, In my day!"

"Have you much wondered, Moon, On your rounds,

Self-wrapt, beyond Earth's bounds?" "Yea, I have wondered, often wondered

At the sounds

Reaching me of the human tune

On my rounds."

"What do you think of it, Moon, As you go?

Is Life much, or no ?"

" $O$, I think of it, often think of it As a show

God ought surely to shut up soon, As I go." 


\section{COPYING ARCHITECTURE IN AN OLD MINSTER}

\section{(Wimborne)}

How smartly the quarters of the hour march by

That the jack-o'-clock never forgets ;

Ding-dong; and before I have traced a cusp's eye,

Or got the true twist of the ogee over,

A double ding-dong ricochetts.

Just so did he clang here before I came,

And so will he clang when I'm gone Through the Minster's cavernous hollows - the same

Tale of hours never more to be will he deliver

To the speechless midnight and dawn!

I grow to conceive it a call to ghosts,

Whose mould lies below and around.

Yes ; the next "Come, come," draws them out from their posts, 
And they gather, and one shade appears, and another,

As the eve-damps creep from the ground.

See-a Courtenay stands by his quatrefoiled tomb,

And a Duke and his Duchess near ;

And one Sir Edmund in columned gloom, And a Saxon king by the presbytery chamber;

And shapes unknown in the rear.

Maybe they have met for a parle on some plan

To better ail-stricken mankind;

I catch their cheepings, though thinner than The overhead creak of a passager's pinion

When leaving land behind.

Or perhaps they speak to the yet unborn, And caution them not to come

To a world so ancient and trouble-torn. Of foiled intents, vain lovingkindness, And ardours chilled and numb.

They waste to fog as I stir and stand, And move from the arched recess, And pick up the drawing that slipped from my hand,

And feel for the pencil I dropped in the cranny

In a moment's forgetfulness. 


\section{TO SHAKESPEARE}

AFTER THREE HUNDRED YEARS

BRIGHT baffling Soul, least capturable of themes,

Thou, who display'dst a life of commonplace,

Leaving no intimate word or personal trace

Of high design outside the artistry

Of thy penned dreams,

Still shalt remain at heart unread eternally.

Through human orbits thy discourse today,

Despite thy formal pilgrimage, throbs on In harmonies that cow Oblivion,

And, like the wind, with all-uncared effect Maintain a sway

Not fore-desired, in tracks unchosen and unchecked. 


\section{TO SHAKESPEARE}

And yet, at thy last breath, with mindless note

The borough clocks but samely tongued the hour,

The Avon just as always glassed the tower, Thy age was published on thy passing-bell But in due rote

With other dwellers' deaths accorded a like knell.

And at the strokes some townsman (met, maybe,

And thereon queried by some squire's good dame

Driving in shopward) may have given thy name,

With, "Yes, a worthy man and well-to-do; Though, as for me,

I knew him but by just a neighbour's nod, 'tis true.

"I' faith, few knew him much here, save by word,

He having elsewhere led his busier life ;

Though to be sure he left with us his wife."

- "Ah, one of the tradesmen's sons, I now recall. . . .

Witty, I've heard. . . .

We did not know him. . . Well, good-day.

Death comes to all." 
So, like a strange bright bird we sometimes find

To mingle with the barn-door brood awhile, Then vanish from their homely domicileInto man's poesy, we wot not whence,

Flew thy strange mind,

Lodged there a radiant guest, and sped for ever thence.

1916. 


\section{QUID HIC AGIS ;}

\section{I}

WhEN I weekly knew

An ancient pew,

And murmured there

The forms of prayer

And thanks and praise

In the ancient ways,

And heard read out

During August drought

That chapter from Kings

Harvest-time brings ;

- How the prophet, broken

By griefs unspoken,

Went heavily away

To fast and to pray,

And, while waiting to die,

The Lord passed by,

And a whirlwind and fire

Drew nigher and nigher,

And a small voice anon

Bade him up and be gone,- 
I did not apprehend As I sat to the end And watched for her smile Across the sunned aisle, That this theme of a seer Which came once a year Might, when sands were heaping, Be like a sweat creeping, Or in any degree Bear on her or on me!

\section{II}

When later, by chance

Of circumstance,

It befel me to read

On a hot afternoon At the lectern there The selfsame words As the lesson decreed, To the gathered few From the hamlets nearFolk of flocks and herds Sitting half aswoon, Who listened thereto As women and men Not overmuch Concerned at suchSo, like them then, I did not see What drought might be 
With me, with her,

As the Kalendar

Moved on, and Time

Devoured our prime.

\section{III}

But now, at last,

When our glory has passed,

And there is no smile

From her in the aisle,

But where it once shone

A marble, men say,

With her name thereon

Is discerned to-day ;

And spiritless

In the wilderness

I shrink from sight

And desire the night,

(Though, as in old wise,

I might still arise,

Go forth, and stand

And prophesy in the land),

I feel the shake

Of wind and earthquake,

And consuming fire

Nigher and nigher,

And the voice catch clear, "What doest thou here ?"

The Spectator: 1916. 


\section{ON A MIDSUMMER EVE}

I IDLY cut a parsley stalk,

And blew therein towards the moon; I had not thought what ghosts would walk With shivering footsteps to my tune.

I went, and knelt, and scooped my hand As if to drink, into the brook, And a faint figure seemed to stand Above me, with the bygone look.

I lipped rough rhymes of chance, not choice, I thought not what my words might be ; There came into my ear a voice That turned a tenderer verse for me. 


\section{TIMING HER}

\section{(Written to an old folk-tune)}

LALAGE's coming :

Where is she now, $\mathrm{O}$ ?

Turning to bow, $\mathrm{O}$,

And smile, is she,

Just at parting,

Parting, parting,

As she is starting

To come to me?

Where is she now, $\mathrm{O}$,

Now, and now, $\mathrm{O}$,

Shadowing a bough, $\mathrm{O}$,

Of hedge or tree

As she is rushing,

Rushing, rushing,

Gossamers brushing

To come to me?

Lalage's coming ;

Where is she now, $\mathrm{O}$; 
Climbing the brow, $\mathrm{O}$, Of hills I see ?

Yes, she is nearing,

Nearing, nearing,

Weathẹr unfearing

To come to me.

Near is she now, $\mathrm{O}$,

Now, and now, $\mathrm{O}$;

Milk the rich cow, O,

Forward the tea ;

Shake the down bed for her,

Linen sheets spread for her,

Drape round the head for her

Coming to me.

Lalage's coming,

Nearer is she now, $\mathrm{O}$,

End anyhow, O,

To-day's husbandry!

Would a gilt chair were mine,

Slippers of vair were mine,

Brushes for hair were mine

Of ivory!

What will she think, O,

She who's so comely, Viewing how homely

A sort are we! 


\section{TIMING $\cdot$ HER}

Nothing resplendent,

No prompt attendant,

Not one dependent

Pertaining to me!

Lalage's coming ;

Where is she now, $O$ ?

Fain I'd avow, $\mathrm{O}$,

Full honestly

Nought here's enough for her,

All is too rough for her,

Even my love for her

Poor in degree.

Nearer is she now, $\mathrm{O}$,

Now, and now, $\mathrm{O}$,

She it is, I vow, O,

Passing the lea.

Rush down to meet her there,

Call out and greet her there,

Never a sweeter there

Crossed to me!

Lalage's come; aye,

Come is she now, $\mathrm{O} ! \ldots$

Does Heaven allow, $\mathrm{O}$,

A meeting to be?

Yes, she is here now,

Here now, here now,

Nothing to fear now,

Here's Lalage! 


\section{BEFORE KNOWLEDGE}

$\mathrm{W}_{\text {HEN I }}$ walked roseless tracks and wide,

Ere dawned your date for meeting me,

$\mathrm{O}$ why did you not cry Halloo Across the stretch between, and say :

"We move, while years as yet divide, On closing lines which - though it be You know me not nor I know youWill intersect and join some day!"

Then well I had borne

Each scraping thorn ; But the winters froze, And grew no rose ;

No bridge bestrode The gap at all ; No shape you showed, And I heard no call! 


\section{THE BLINDED BIRD}

So zestfully canst thou sing?

And all this indignity,

With God's consent, on thee!

Blinded ere yet a-wing

By the red-hot needle thou,

I stand and wonder how

So zestfully thou canst sing !

Resenting not such wrong,

Thy grievous pain forgot,

Eternal dark thy lot,

Groping thy whole life long,

After that stab of fire ;

Enjailed in pitiless wire ;

Resenting not such wrong!

Who hath charity? This bird.

Who suffereth long and is kind,

Is not provoked, though blind

And alive ensepulchred?

Who hopeth, endureth all things?

Who thinketh no evil, but sings ?

Who is divine? This bird. 


\section{"THE WIND BLEW WORDS"}

ThE wind blew words along the skies, And these it blew to me

Through the wide dusk: "Lift up your eyes,

Behold this troubled tree,

Complaining as it sways and plies ;

It is a limb of thee.

"Yea, too, the creatures sheltering round-Dumb figures, wild and tame, Yea, too, thy fellows who aboundEither of speech the same

Or far and strange-black, dwarfed, and browned,

They are stuff of thy own frame."

I moved on in a surging awe

Of inarticulateness

At the pathetic Me I saw

In all his huge distress,

Making self-slaughter of the law

To kill, break, or suppress. 


\section{THE FADED FACE}

How was this I did not see Such a look as here was shown Ere its womanhood had blown

Past its first felicity?-

That I did not know you young,

Faded Face,

Know you young !

Why did Time so ill bestead

That I heard no voice of yours

Hail from out the curved contours

Of those lips when rosy red;

Listed not the songs they sung,

Faded Face,

Songs they sung !

By these blanchings, blooms of old, And the relics of your voiceLeavings rare of rich and choice From your early tone and mouldLet me mourn,--aye, overwrung,

Faded Face, Overwrung! 


\section{THE RIDDLE}

I

Stretching eyes west

Over the sea,

Wind foul or fair,

Always stood she

Prospect-impressed ;

Solely out there

Did her gaze rest,

Never elsewhere

Seemed charm to be.

\section{II}

Always eyes east

Ponders she now-

As in devotion-

Hills of blank brow

Where no waves plough.

Never the least

Room for emotion

Drawn from the ocean

Does she allow. 


\section{THE DUEL}

"I AM here to time, you see;

The glade is well-screened-eh?-against alarm ;

Fit place to vindicate by my arm The honour of my spotless wife, Who scorns your libel upon her life In boasting intimacy!

" A All hush-offerings you'll spurn, My husband. Two must come ; one only go,' She said. 'That he'll be you I know ; To faith like ours Heaven will be just, And I shall abide in fullest trust

Your speedy glad return.'"

"Good. Here am also I ;

And we'll proceed without more waste of words

To warm your cockpit. Of the swords 
Take you your choice. I shall thereby Feel that on me no blame can lie,

Whatever Fate accords."

So stripped they there, and fought, And the swords clicked and scraped, and the onsets sped;

Till the husband fell ; and his shirt was red

With streams from his heart's hot cistern.

Nought

Could save him now; and the other, wrought

Maybe to pity, said :

"Why did you urge on this?

Your wife assured you; and 't had better been

That you had let things pass, serene

In confidence of long-tried bliss,

Holding there could be nought amiss

In what my words might mean."

Then, seeing nor ruth nor rage

Could move his foeman more-now Death's deaf thrall-

He wiped his steel, and, with a call Like turtledove to dove, swift broke Into the copse, where under an oak

His horse cropt, held by a page. 


\section{THE DUEL}

"All's over, Sweet," he cried

To the wife, thus guised ; for the young page was she.

"'Tis as we hoped and said 't would be. He never guessed. ... We mount and ride

To where our love can reign uneyed. He's clay, and we are free." 


\section{AT MAYFAIR LODGINGS}

How could I be aware,

The opposite window eyeing As I lay listless there,

That through its blinds was dying

One I had rated rare

Before I had set me sighing

For another more fair?

Had the house-front been glass,

My vision unobscuring,

Could aught have come to pass

More happiness-insuring

To her, loved as a lass

When spouseless, all-alluring?

I reckon not, alas!

So, the square window stood,

Steadily night-long shining

In my close neighbourhood,

Who looked forth undivining

That soon would go for good

One there in pain reclining, Unpardoned, unadieu'd. 
Silently screened from view

Her tragedy was ending

That need not have come due

$\mathrm{Had}$ she been less unbending.

How near, near were we two

At that last vital rending, And neither of us knew! 


\section{TO MY FATHER'S VIOLIN}

Does he want you down there

In the Nether Glooms where

The hours may be a dragging load upon him,

- As he hears the axle grind

Round and round

Of the great world, in the blind

Still profound

Of the night-time? He might liven at the sound

Of your string, revealing you had not forgone him.

In the gallery west the nave,

But a few yards from his grave,

Did you, tucked beneath his chin, to his bowing

Guide the homely harmony

Of the quire

Who for long years strenuously-

Son and sire-

Caught the strains that at his fingering low or higher

From your four thin threads and eff-holes came outflowing. 


\section{TO MY FATHER'S VIOLIN 45}

And, too, what merry tunes

He would bow at nights or noons

That chanced to find him bent to lute a measure,

When he made you speak his heart

As in dream,

Without book or music-chart,

On some theme

Elusive as a jack-o'-lanthorn's gleam,

And the psalm of duty shelved for trill of pleasure.

Well, you can not, alas,

The barrier overpass

That screens him in those Mournful Meads hereunder,

Where no fiddling can be heard

In the glades

Of silentness, no bird

Thrills the shades;

Where no viol is touched for songs or serenades,

No bowing wakes a congregation's wonder.

He must do without you now,

Stir you no more anyhow

To yearning concords taught you in your glory ; 


\section{TO MY FATHER'S VIOLIN}

\section{While, your strings a tangled wreck, \\ Once smart drawn,}

Ten worm-wounds in your neck,

Purflings wan

With dust-hoar, here alone I sadly con

Your present dumbness, shape your olden story.

1916. 


\section{THE STATUE OF LIBERTY}

THis statue of Liberty, busy man, Here erect in the city square,

I have watched while your scrubbings, this early morning, Strangely wistful, And half tristful,

Have turned her from foul to fair ;

With your bucket of water, and mop, and brush,

Bringing her out of the grime

That has smeared her during the smokes of winter

With such glumness

In her dumbness,

And aged her before her time.

You have washed her down with motherly care-

Head, shoulders, arm, and foot,

To the very hem of the robes that drape her- 
48 THE STATUE OF LIBERTY

\section{All expertly \\ And alertly,}

Till a long stream, black with soot,

Flows over the pavement to the road, And her shape looms pure as snow :

I read you are hired by the City guardiansMay be yearly,

Or once merely-

To treat the statues so ?

"Oh, I'm not hired by the Councilmen To cleanse the statues here.

I do this one as a self-willed duty,

Not as paid to,

Or at all made to,

But because the doing is dear."

Ah, then I hail you brother and friend!

Liberty's knight divine.

What you have done would have been my doing,

Yea, most verily,

Well, and thoroughly,

Had but your courage been mine!

“ Oh I care not for Liberty's mould, Liberty charms not me ;

What's Freedom but an idler's vision, 


\section{THE STATUE OF LIBERTY 49}

Vain, pernicious,

Often vicious,

Of things that cannot be!

"Memory it is that brings me to thisOf a daughter-my one sweet own. She grew a famous carver's model,

One of the fairest And of the rarest :-

She sat for the figure as shown.

"But alas, she died in this distant place Before I was warned to betake Myself to her side ! . . And in love of my darling,

In love of the fame of her, And the good name of her, I do this for her sake."

Answer I gave not. Of that form

The carver was I at his side ;

His child, my model, held so saintly,

Grand in feature,

Gross in nature,

In the dens of vice had died. 


\section{THE BACKGROUND AND THE FIGURE}

\section{(Lover's Ditty)}

I THIN K of the slope where the rabbits fed, Of the periwinks' rockwork lair, Of the fuchsias ringing their bells of redAnd the something else seen there.

Between the blooms where the sod basked bright,

By the bobbing fuchsia trees,

Was another and yet more eyesome sightThe sight that richened these.

I shall seek those beauties in the spring,

When the days are fit and fair, But only as foils to the one more thing That also will flower there! 


\section{THE CHANGE}

Out of the past there rises a week-

Who shall read the years $\mathrm{O}$ !-

Out of the past there rises a week

Enringed with a purple zone.

Out of the past there rises a week

When thoughts were strung too thick to speak,

And the magic of its lineaments remains with me alone.

In that week there was heard a singingWho shall spell the years, the years!-

In that week there was heard a singing,

And the white owl wondered why.

In that week, yea, a voice was ringing,

And forth from the casement were candles

flinging

Radiance that fell on the deodar and lit up the path thereby.

Could that song have a mocking note ?Who shall unroll the years $\mathrm{O}$ !- 
Could that song have a mocking note To the white owl's sense as it fell ?

Could that song have a mocking note As it trilled out warm from the singer's throat,

And who was the mocker and who the mocked when two felt all was well ?

In a tedious trampling crowd yet later-

Who shall bare the years, the years!-

In a tedious trampling crowd yet later,

When silvery singings were dumb;

In a crowd uncaring what time might fate her,

Mid murks of night I stood to await her, And the twanging of iron wheels gave out the signal that she was come.

She said with a travel-tired smile-

Who shall lift the years $\mathrm{O} !-$

She said with a travel-tired smile,

Half scared by scene so strange ;

She said, outworn by mile on mile,

The blurred lamps wanning her face the while,

"O Love, I am here ; I am with you!" . . . $\mathrm{Ah}$, that there should have come a change! 


\section{THE CHANGE}

$\mathrm{O}$ the doom by someone spokenWho shall unseal the years, the years !-

$O$ the doom that gave no token, When nothing of bale saw we :

$\mathrm{O}$ the doom by someone spoken,

$\mathrm{O}$ the heart by someone broken,

The heart whose sweet reverberances are all time leaves to me.

Jan.-Feb. 1913. 


\section{SITTING ON THE BRIDGE}

\section{(Echo of an old song)}

SitTing on the bridge

Past the barracks, town and ridge, At once the spirit seized us To sing a song that pleased usAs "The Fifth" were much in rumour ; It was "Whilst I'm in the humour, Take me, Paddy, will you now ?" And a lancer soon drew nigh, And his Royal Irish eye Said, "Willing, faith, am I, $\mathrm{O}$, to take you anyhow, dears, To take you anyhow."

But, lo !-dad walking by, Cried, "What, you lightheels! Fie ! Is this the way you roam And mock the sunset gleam?" And he marched us straightway home, Though we said, "We are only, daddy, Singing, "Will you take me, Paddy ?'" 


\section{SITTING ON THE BRIDGE 55}

-Well, we never saw from then

If we sang there anywhen,

The soldier dear again,

Except at night in dream-time,

Except at night in dream.

Perhaps that soldier's fighting

In a land that's far away,

Or he may be idly plighting

Some foreign hussy gay ;

Or perhaps his bones are whiting

In the wind to their decay !...

Ah! - does he mind him how

The girls he saw that day

On the bridge, were sitting singing

At the time of curfew-ringing,

"Take me, Paddy ; will you now, dear? Paddy, will you now ?"

Grey's Bridgr. 


\section{THE YOUNG CHURCHWARDEN}

WHEN he lit the candles there, And the light fell on his hand, And it trembled as he scanned Her and me, his vanquished air Hinted that his dream was done, And I saw he had begun To understand.

When Love's viol was unstrung, Sore I wished the hand that shook Had been mine that shared her book While that evening hymn was sung, His the victor's, as he lit Candles where he had bidden us sit With vanquished look.

Now her dust lies listless there, His afar from tending hand, What avails the victory scanned? Does he smile from upper air : "Ah, my friend, your dream is done ; And 'tis you who have begun To understand !". 


\section{"I TRAVEL AS A PHANTOM NOW"}

I TRAVEL as a phantom now, For people do not wish to see In flesh and blood so bare a bough As Nature makes of me.

And thus I visit bodiless

Strange gloomy households often at odds, And wonder if Man's consciousness Was a mistake of God's.

And next I meet you, and I pause, And think that if mistake it were, As some have said, $\mathrm{O}$ then it was

One that I well can bear!

1915. 


\section{LINES}

TO A MOVEMENT IN MOZART'S E-FLAT

SYMPHONY

SHow me again the time

When in the Junetide's prime

We flew by meads and mountains northerly !-

Yea, to such freshness, fairness, fulness, fineness, freeness,

Love lures life on.

Show me again the day

When from the sandy bay

We looked together upon the pestered sea!-

Yea, to such surging, swaying, sighing, swelling, shrinking,

Love lures life on.

Show me again the hour

When by the pinnacled tower

We eyed each other and feared futurity!- 


\section{LINES TO A SYMPHONY}

Yea, to such bodings, broodings, beatings, blanchings, blessings,

Love lures life on.

Show me again just this :

The moment of that kiss

Away from the prancing folk, by the strawberry-tree!-

Yea, to such rashness, ratheness, räreness, ripeness, richness,

Love lures life on.

Begun November 1898. 


\section{"IN THE SEVENTIES"}

“Qui deridetur ab amico suo sicut ego."-Јов.

IN the seventies I was bearing in my breast,

Penned tight,

Certain starry thoughts that threw a magic light

On the worktimes and the soundless hours of rest

In the seventies; aye, I bore them in my breast

Penned tight.

In the seventies when my neighbours-even my friend-

Saw me pass,

Heads were shaken, and I heard the words, "Alas,

For his onward years and name unless he mend!"

In the seventies, when my neighbours and my friend

Saw me pass. 


\section{"IN THE SEVENTIES"}

In the seventies those who met me did not know

$$
\text { Of the vision }
$$

That immuned me from the chillings of misprision

And the damps that choked my goings to and fro

In the seventies; yea, those nodders did not know

$$
\text { Of the vision. }
$$

In the seventies nought could darken or destroy it,

$$
\text { Locked in me, }
$$

Though as delicate as lamp-worm's lucency ;

Neither mist nor murk could weaken or alloy it

In the seventies!-could not darken or destroy it,

Locked in me. 


\section{THE PEDIGREE}

\section{BENT in the deep of night}

Over a pedigree the chronicler gave As mine; and as I bent there, halfunrobed,

The uncurtained panes of my window-square let in the watery light Of the moon in its old age : And green-rheumed clouds were hurrying past where mute and cold it globed Like a drifting dolphin's eye seen through a lapping wave.

So, scanning my sire-sown tree, And the hieroglyphs of this spouse tied to that,

With offspring mapped below in lineage,

Till the tangles troubled mie, 
The branches seemed to twist into a seared and cynic face

Which winked and tokened towards the window like a Mage

Enchanting me to gaze again thereat.

\section{III}

It was a mirror now,

And in it a long perspective I could

trace

Of my begetters, dwindling backward each past each

All with the kindred look,

Whose names had since been inked down in their place

On the recorder's book,

Generation and generation of my mien, and build, and brow.

And then did I divine

That every heave and coil and move I made

Within my brain, and in my mood and speech,

Was in the glass portrayed

As long forestalled by their so making it : 


\section{THE PEDIGREE}

The first of them, the primest fuglemen of my line,

Being fogged in far antiqueness past surmise and reason's reach.

\section{V}

Said I then, sunk in tone, "I am merest mimicker and counterfeit!-

Though thinking, I am I, And what I do I do myself alone." -The cynic twist of the page thereat unknit

Back to its normal figure, having wrought its purport wry,

The Mage's mirror left the windowsquare,

And the stained moon and drift retook their places there.

1916. 


\title{
HIS HEART
}

\author{
A WOMAN'S DREAM
}

Ar midnight, in the room where he lay dead

Whom in his life I had never clearly read, I thought if I could peer into that citadel

His heart, I should at last know full and well

What hereto had been known to him alone, Despite our long sit-out of years foreflown, "And if," I said, "I do this for his memory's sake,

It would not wound him, even if he could wake."

So I bent over him. He seemed to smile With a calm confidence the whole long while

That I, withdrawing his heart, held it and, bit by bit,

Perused the unguessed things found written on it.

M V

65

F 
It was inscribed like a terrestrial sphere

With quaint vermiculations close and clear-

His graving. Had I known, would I have risked the stroke

Its reading brought, and my own heart nigh broke!

Yes, there at last, eyes opened, did I see His whole sincere symmetric history ;

There were his truth, his simple singlemindedness,

Strained, maybe, by time's storms, but there no less.

There were the daily deeds from sun to sun In blindness, but good faith, that he had done ;

There were regrets, at instances wherein he swerved

(As he conceived) from cherishings I had deserved.

There were old hours all figured down as bliss-

Those spent with me-(how little had I thought this!)

There those when, at my absence, whether he slept or waked,

(Though I knew not 'twas so!) his spirit ached. 


\section{HIS HEART}

There that when we were severed, how day dulled

Till time joined us anew, was chronicled : And arguments and battlings in defence of me

That heart recorded clearly and ruddily.

I put it back, and left him as he lay

While pierced the morning pink and then the gray

Into each dreary room and corridor around, Where I shall wait, but his step will not sound. 


\section{WHERE THEY LIVED}

Dishevelned leaves creep down

Upon that bank to-day,

Some green, some yellow, and some pale brown;

The wet bents bob and sway;

The once warm slippery turf is sodden

Where we laughingly sat or lay.

The summerhouse is gone,

Leaving a weedy space ;

The bushes that veiled it once have grown

Gaunt trees that interlace,

Through whose lank limbs I see too clearly

The nakedness of the place.

And where were hills of blue,

Blind drifts of vapour blow,

And the names of former dwellers few,

If any, people know,

And instead of a voice that called, "Come in, Dears,"

Time calls, " Pass below !" 


\section{THE OCCULTATION}

WHEN the cloud shut down on the morning shine,

And darkened the sun,

I said, "So ended that joy of mine

Years back begun."

But day continued its lustrous roll In upper air ;

And did my late irradiate soul

Live on somewhere? 


\section{LIFE LAUGHS ONWARD}

RAMBLING I looked for an old abode Where, years back, one had lived I knew ; Its site a dwelling duly showed, But it was new.

I went where, not so long ago, The sod had riven two breasts asunder ; Daisies throve gaily there, as though No grave were under.

I walked along a terrace where Loud children gambolled in the sun ; The figure that had once sat there Was missed by none.

Life laughed and moved on unsubdued, I saw that Old succumbed to Young: 'Twas well. My too regretful mood Died on my tongue. 


\section{THE PEACE-OFFERING}

IT was but a little thing,

Yet I knew it meant to me

Ease from what had given a sting

To the very birdsinging

Latterly.

But I would not welcome it ;

And for all I then declined

$O$ the regrettings infinite

When the night-processions flit

Through the mind! 


\section{"SOMETHING TAPPED"}

Something tapped on the pane of my room When there was never a trace Of wind or rain, and I saw in the gloom My weary Belovéd's face.

"O I am tired of waiting," she said, "Night, morn, noon, afternoon ; So cold it is in my lonely bed, And I thought you would join me soon!"

I rose and neared the window-glass, But vanished thence had she:

Only a pallid moth, alas, Tapped at the pane for me.

August 1913. 


\section{THE WOUND}

I CLIMBED to the crest, And, fog-festooned, The sun lay west

Like a crimson wound :

Like that wound of mine

Of which none knew, For I'd given no sign

That it pierced me through. 


\section{A MERRYMAKING IN QUESTION}

"I will get a new string for my fiddle, And call to the neighbours to come, And partners shall dance down the middle Until the old pewter-wares hum : And we'll sip the mead, cyder, and rum !"

From the night came the oddest of answers :

A hollow wind, like a bassoon, And headstones all ranged up as dancers, And cypresses droning a croon, And gurgoyles that mouthed to the tune. 


\section{"I SAID AND SANG HER EXCELLENCE"}

(Fickle Lover's Song)

I SAID and sang her excellence :

They called it laud undue.

(Have your way, my heart, $\mathrm{O}$ !)

Yet what was homage far above The plain deserts of my olden Love Proved verity of my new.

"She moves a sylph in picture-land,

Where nothing frosts the air :"

(Have your way, my heart, $\mathrm{O}$ !)

"To all winged pipers overhead She is known by shape and song," I said,

Conscious of licence there.

I sang of her in a dim old hall Dream-built too fancifully,

(Have your way, my heart, $\mathrm{O}$ !)

But lo, the ripe months chanced to lead My feet to such a hall indeed, Where stood the very She. 


\section{6 "I SANG HER EXCELLENCE"}

Strange, startling, was it then to learn

I had glanced down unborn time,

(Have your way, my heart, $\mathrm{O}$ !)

And prophesied, whereby I knew

That which the years had planned to do

In warranty of my rhyme.

By Rushy-Pond. 


\section{A JANUARY NIGHT}

\section{(1879)}

THE rain smites more and more, The east wind snarls and sneezes ; Through the joints of the quivering door The water wheezes.

The tip of each ivy-shoot Writhes on its neighbour's face ; There is some hid dread afoot That we cannot trace.

Is it the spirit astray

Of the man at the house below

Whose coffin they took in to-day?

We do not know. 


\section{A KISS}

$\mathrm{By}$ a wall the stranger now calls his,

Was born of old a particular kiss,

Without forethought in its genesis ;

Which in a trice took wing on the air.

And where that spot is nothing shows :

There ivy calmly grows,

And no one knows

What a birth was there!

That kiss is gone where none can tellNot even those who felt its spell :

It cannot have died; that know we well. Somewhere it pursues its flight,

One of a long procession of sounds

Travelling aethereal rounds

Far from earth's bounds

In the infinite. 


\section{THE ANNOUNCEMENT}

THEY came, the brothers, and took two chairs

In their usual quiet way ;

And for a time we did not think

They had much to say.

And they began and talked awhile

Of ordinary things,

Till spread that silence in the room

A pent thought brings.

And then they said: "The end has come.

Yes : it has come at last."

And we looked down, and knew that day

A spirit had passed. 


\section{THE OXEN}

Christmas Eve, and twelve of the clock.

"Now they are all on their knees,"

An elder said as we sat in a flock

By the embers in hearthside ease.

We pictured the meek mild creatures where They dwelt in their strawy pen,

Nor did it occur to one of us there

To doubt they were kneeling then.

So fair a fancy few would weave

In these years! Yet, I feel,

If someone said on Christmas Eve,

"Come; see the oxen kneel

"In the lonely barton by yonder coomb

Our childhood used to know,"

I should go with him in the gloom,

Hoping it might be so.

1915. 


\section{THE TRESSES}

"When the air was damp

It made my curls hang slack

As they kissed my neck and back

While I footed the salt-aired track

I loved to tramp.

"When it was dry

They would roll up crisp and tight As I went on in the light

Of the sun, which my own sprite Seemed to outvie.

"Now I am old;

And have not one gay curl

As I had when a girl

For dampness to unfurl

Or sun uphold!" 


\section{THE PHOTOGRAPH}

$T_{H E}$ flame crept up the portrait line by line As it lay on the coals in the silence of night's profound,

And over the arm's incline,

And along the marge of the silk work superfine, And gnawed at the delicate bosom's defenceless round.

Then I vented a cry of hurt, and averted my eyes ;

The spectacle was one that I could not bear,

To my deep and sad surprise ;

But, compelled to heed, I again looked furtivewise

Till the flame had eaten her breasts, and mouth, and hair.

"Thank God, she is out of it now!" I said at last,

In a great relief of heart when the thing was done

That had set my soul aghast, 
And nothing was left of the picture unsheathed from the past

But the ashen ghost of the card it had figured on.

She was a woman long hid amid packs of years,

She might have been living or dead; she was lost to my sight,

And the deed that had nigh drawn tears Was done in a casual clearance of life's arrears; But I felt as if I had put her to death that night $! \ldots$

-Well; she knew nothing thereof did she survive,

And suffered nothing if numbered among the dead ;

Yet-yet-if on earth alive

Did she feel a smart, and with vague strange anguish strive?

If in heaven, did she smile at me sadly and shake her head? 


\section{ON A HEATH}

I coulD hear a gown-skirt rustling Before I could see her shape, Rustling through the heather That wove the common's drape, On that evening of dark weather When I hearkened, lips agape.

And the town-shine in the distance

Did but baffle here the sight, And then a voice flew forward:

Dear, is't you ? I fear the night!" And the herons flapped to norward In the firs upon my right.

There was another looming Whose life we did not see ;

There was one stilly blooming Full nigh to where walked we ;

There was a shade entombing All that was bright of me. 


\section{AN ANNIVERSARY}

IT was at the very date to which we have come,

In the month of the matching name, When, at a like minute, the sun had upswum,

Its couch-time at night being the same. And the same path stretched here that people now follow,

And the same stile crossed their way,

And beyond the same green hillock and hollow

The same horizon lay;

And the same man pilgrims now hereby who pilgrimed here that day.

Let so much be said of the date-day's sameness ;

But the tree that neighbours the track, And stoops like a pedlar afflicted with lameness,

Knew of no sogged wound or windcrack. 
And the stones of that wall were not enshrouded

With mosses of many tones,

And the garth up afar was not overcrowded

With a multitude of white stones,

And the man's eyes then were not so sunk that you saw the socket-bones.

Kingston-Maurward Eweleasu. 


\section{"BY THE RUNIC STONE"}

('Two who became a story)

By the Runic Stone

They sat, where the grass sloped down, And chattered, he white-hatted, she in brown, Pink-faced, breeze-blown.

Rapt there alone

In the transport of talking so

In such a place, there was nothing to let them know

What hours had flown.

And the die thrown

By them heedlessly there, the dent

It was to cut in their encompassment,

Were, too, unknown.

It might have strown

Their zest with qualms to see, As in a glass, Time toss their history

From zone to zone! 


\section{THE PINK FROCK}

“O MY pretty pink frock, I sha'n't be able to wear it! Why is he dying just now?

I hardly can bear it!

" He might have contrived to live on ; But they say there's no hope whatever : And must I shut myself up, And go out never?

"O my pretty pink frock, Puff-sleeved and accordion-pleated! He might have passed in July, And not so cheated!' 


\section{TRANSFORMATIONS}

Portion of this yew

Is a man my grandsire knew,

Bosomed here at its foot:

This branch may be his wife,

A ruddy human life

Now turned to a green shoot.

These grasses must be made Of her who often prayed, Last century, for repose ; And the fair girl long ago Whom I often tried to know May be entering this rose.

So, they are not underground, But as nerves and veins abound In the growths of upper air, And they feel the sun and rain, And the energy again

That made them what they were! 


\section{IN HER PRECINCTS}

HER house looked cold from the foggy lea, And the square of each window a dull black blur

Where showed no stir :

Yes, her gloom within at the lack of me Seemed matching mine at the lack of her.

The black squares grew to be squares of light As the eveshade swathed the house and lawn, And viols gave tone;

There was glee within. And I found that night

The gloom of severance mine alone.

Kingston-Maurward Park. 


\section{THE LAST SIGNAL}

(Oct. I I, I 886)

\section{A MEMORY OF WILLIAM BARNES}

Silently I footed by an uphill road

That led from my abode to a spot yewboughed;

Yellowly the sun sloped low down to westward,

And dark was the east with cloud.

Then, below the shadow of that livid sad east,

Where the light was least, and a gate stood wide,

Flashed back the fire of the sun that was facing it,

Like a brief blaze on that side.

Looking hard and harder I knew what it meant-

The sudden shine sent from the livid east scene ; 
It meant the west mirrored by the coffin of my friend there, Turning to the road from his green,

To take his last journey forth-he who in his prime

Trudged so many a time from that gate athwart the land!

Thus a farewell to me he signalled on his grave-way,

As with a wave of his hand.

Winterborne-Came Path. 


\section{THE HOUSE OF SILENCE}

"Тнат is a quiet place-

That house in the trees with the shady lawn." "-If, child, you knew what there goes on You would not call it a quiet place. Why, a phantom abides there, the last of its race,

And a brain spins there till dawn."

"But I see nobody there,-

Nobody moves about the green,

Or wanders the heavy trees between." "-Ah, that's because you do not bear The visioning powers of souls who dare To pierce the material screen.

"Morning, noon, and night, Mid those funereal shades that seem The uncanny scenery of a dream, Figures dance to a mind with sight, And music and laughter like floods of light Make all the precincts gleam. 


\section{THE HOUSE OF SILENCE}

"It is a poet's bower,

Through which there pass, in fleet arrays,

Long teams of all the years and days, Of joys and sorrows, of earth and heaven, That meet mankind in its ages seven,

An aion in an hour." 


\section{GREAT THINGS}

SweEt cyder is a great thing,

A great thing to me, Spinning down to Weymouth town By Ridgway thirstily, And maid and mistress summoning Who tend the hostelry :

$\mathrm{O}$ cyder is a great thing, A great thing to me!

The dance it is a great thing, A great thing to me, With candles lit and partners fit For night-long revelry ;

And going home when day-dawning Peeps pale upon the lea:

$\mathrm{O}$ dancing is a great thing, A great thing to me!

Love is, yea, a great thing, A great thing to me, When, having drawn across the lawn In darkness silently. 
A figure flits like one a-wing Out from the nearest tree :

$O$ love is, yes, a great thing, Aye, greatest thing to me!

Will these be always great things,

Greatest things to me ? . . .

Let it befall that One will call, "Soul, I have need of thee" :

What then? Joy-jaunts, impassioned flings,

Love, and its ecstasy, Will always have been great things, Greatest things to me ! 


\section{THE CHIMES}

That morning when I trod the town The twitching chimes of long renown Played out to me

The sweet Sicilian sailors' tune, And I knew not if late or soon My day would be :

A day of sunshine beryl-bright And windless; yea, think as I might, I could not say,

Even to within years' measure, when One would be at my side who then

Was far away.

When hard utilitarian times

Had stilled the sweet Saint-Peter's chimes

I learnt to see

That bale may spring where blisses are, And one desired might be afar Though near to me. 


\section{THE FIGURE IN THE SCENE}

IT pleased her to step in front and sit Where the cragged slope was green,

While I stood back that I might pencil it With her amid the scene;

Till it gloomed and rained;

But I kept on, despite the drifting wet

That fell and stained

My draught, leaving for curious quizzings yet The blots engrained.

And thus I drew her there alone,

Seated amid the gauze

Of moisture, hooded, only her outline shown, With rainfall marked across.

-Soon passed our stay;

Yet her rainy form is the Genius still of the spot,

Immutable, yea,

'Though the place now knows her no more, and has known her not

Ever since that day.

From an old note. 


\section{"WHY DID I SKETCH"}

Why did I sketch an upland green, And put the figure in Of one on the spot with me ?-

For now that one has ceased to be seen

The picture waxes akin

To a wordless irony.

If you go drawing on down or cliff .

Let no soft curves intrude

Of a woman's silhouette,

But show the escarpments stark and stiff

As in utter solitude ;

So shall you half forget.

Let me sooner pass from sight of the sky

Than again on a thoughtless day

Limn, laugh, and sing, and rhyme

With a woman sitting near, whom I

Paint in for love, and who may

Be called hence in my time!

From an old note. 


\section{CONJECTURE}

I $\mathrm{F}$ there were in my kalendar

No Emma, Florence, Mary,

What would be my existence now-

A hermit's ?-wanderer's weary?-

How should I live, and how

Near would be death, or far?

Could $\cdot$ it have been that other eyes

Might have uplit my highway?

That fond, sad, retrospective sight

Would catch from this dim byway

Prized figures different quite

From those that now arise?

With how strange aspect would there creep

The dawn, the night, the daytime,

If memory were not what it is

In song-time, toil, or pray-time.-

$O$ were it else than this,

I'd pass to pulseless sleep! 


\section{THE BLOW}

THaT no man schemed it is my hope-

Yea, that it fell by will and scope

Of That Which some enthrone,

And for whose meaning myriads grope.

For I would not that of my kind

There should, of his unbiassed mind,

Have been one known

Who such a stroke could have designed;

Since it would augur works and ways

Below the lowest that man assays

To have hurled that stone

Into the sunshine of our days !

And if it prove that no man did, And that the Inscrutable, the Hid,

Was cause alone

Of this foul crash our lives amid,

I'll go in due time, and forget

In some deep graveyard's oubliette The thing whereof I groan,

And cease from troubling; thankful yet 


\section{THE BLOW}

Time's finger should have stretched to show No aimful author's was the blow

That swept us prone, But the Immanent Doer's That doth not know,

Which in some age unguessed of us May lift Its blinding incubus, And see, and own : "It grieves me I did thus and thus!" 


\section{LOVE THE MONOPOLIST}

\section{(Young Lover's Reverie)}

THE train draws forth from the station-yard,

And with it carries me.

I rise, and stretch out, and regard

The platform left, and see

An airy slim blue form there standing,

And know that it is she.

While with strained vision I watch on,

The figure turns round quite

To greet friends gaily; then is gone. . . .

The import may be slight,

But why remained she not hard gazing

Till I was out of sight?

"O do not chat with others there,"

I brood. "They are not I.

$\mathrm{O}$ strain your thoughts as if they were

Gold bands between us; eye

All neighbour scenes as so much blankness

Till I again am by !

103 


\section{IO4 LOVE THE MONOPOLIST}

"A troubled soughing in the breeze

And the sky overhead

Let yourself feel ; and shadeful trees,

Ripe corn, and apples red,

Read as things barren and distasteful

While we are separated!

"When I come back uncloak your gloom,

And let in lovely day ;

Then the long dark as of the tomb

Can well be thrust away

With sweet things I shall have to practise, And you will have to say!"

Begun 1871: finished-. 


\section{AT MIDDLE-FIELD GATE IN FEBRUARY}

THE bars are thick with drops that show As they gather themselves from the fog Like silver buttons ranged in a row, And as evenly spaced as if measured, although

They fall at the feeblest jog.

They load the leafless hedge hard by, And the blades of last year's grass, While the fallow ploughland turned up nigh In raw rolls, clammy and clogging lieToo clogging for feet to pass.

How dry it was on a far-back day

When straws hung the hedge and around,

When amid the sheaves in amorous play

In curtained bonnets and light array

Bloomed a bevy now underground!

Bockhampton LaNe. 


\section{THE YOUTH WHO CARRIED A LIGHT}

I saw him pass as the new day dawned,

Murmuring some musical phrase ;

Horses were drinking and floundering in the pond,

And the tired stars thinned their gaze ;

Yet these were not the spectacles at all that he conned,

But an inner one, giving out rays.

Such was the thing in his eye, walking there, The very and visible thing,

A close light, displacing the gray of the morning air,

And the tokens that the dark was taking wing ;

And was it not the radiance of a purpose rare That might ripe to its accomplishing?

What became of that light? I wonder still its fate!

Was it quenched ere its full apogee? 


\section{YOUTH WHO CARRIED A LIGHT 107}

Did it struggle frail and frailer to a beam emaciate?

Did it thrive till matured in verity?

Or did it travel on, to be a new young dreamer's freight,

And thence on infinitely?

1915. 


\section{THE HEAD ABOVE THE FOG}

Something do I see

Above the fog that sheets the mead, A figure like to life indeed, Moving along with spectre-speed, Seen by none but me.

O the vision keen!Tripping along to me for love As in the flesh it used to move, Only its hat and plume above The evening fog-fleece seen.

In the day-fall wan, When nighted birds break off their song, Mere ghostly head it skims along, Just as it did when warm and strong, Body seeming gone.

Such it is I see Above the fog that sheets the meadYea, that which once could breathe and plead!-

Skimming along with spectre-speed

To a last tryst with me. 


\section{OVERLOOKING THE RIVER STOUR}

The swallows flew in the curves of an eight

Above the river-gleam

In the wet June's last beam :

Like little crossbows animate

The swallows flew in the curves of an eight

Above the river-gleam.

Planing up shavings of crystal spray

A moor-hen darted out

From the bank thereabout,

And through the stream-shine ripped his way ;

Planing up shavings of crystal spray

A moor-hen darted out.

Closed were the kingcups; and the mead

Dripped in monotonous green,

Though the day's morning sheen

Had shown it golden and honeybee'd ;

Closed were the kingcups; and the mead

Dripped in monotonous green. 


\section{IO OVERLOOKING THE STOUR}

And never I turned my head, alack,

While these things met my gaze

Through the pane's drop-drenched

glaze,

To see the more behind my back. ...

O never I turned, but let, alack,

These less things hold my gaze! 


\section{THE MUSICAL BOX}

\section{Lifelong to be}

Seemed the fair colour of the time ;

That there was standing shadowed near A spirit who sang to the gentle chime Of the self-struck notes, I did not hear, I did not see.

Thus did it sing

To the mindless lyre that played indoors

As she came to listen for me without : "O value what the nonce outpoursThis best of life-that shines about

Your welcoming!"

I had slowed along

After the torrid hours were done, Though still the posts and walls and road Flung back their sense of the hot-faced sun, And had walked by Stourside Mill, where broad Stream-lilies throng. 


\section{And I descried}

The dusky house that stood apart, And her, white-muslined, waiting there In the porch with high-expectant heart, While still the thin mechanic air

Went on inside.

\section{At whiles would flit}

Swart bats, whose wings, be-webbed and tanned,

Whirred like the wheels of ancient clocks :

She laughed a hailing as she scanned

$\mathrm{Me}$ in the gloom, the tuneful box

Intoning it.

Lifelong to be

I thought it. That there watched hard by

A spirit who sang to the indoor tune,

"O make the most of what is nigh!"

I did not hear in my dull soul-swoon-

I did not see. 


\section{ON STURMINSTER FOOT-BRIDGE}

Reticulations creep upon the slack stream's face

When the wind skims irritably past,

The current clucks smartly into each hollow place

That years of flood have scrabbled in the pier's sodden base ;

The floating-lily leaves rot fast.

On a roof stand the swallows ranged in wistful waiting rows,

Till they arrow off and drop like stones Among the eyot-withies at whose foot the river flows ;

And beneath the roof is she who in the dark world shows

As a lattice-gleam when midnight moans. 


\section{ROYAL SPONSORS}

"THE king and the queen will stand to the child ;

'Twill be handed down in song;

And it's no more than their deserving, With my lord so faithful at Court so long, And so staunch and strong.

"O never before was known such a thing!

'Twill be a grand time for all ;

And the beef will be a whole-roast bullock, And the servants will have a feast in the hall,

And the ladies a ball.

“While from Jordan's stream by a traveller, In a flagon of silver wrought, And by caravan, stage-coach, wain, and waggon

A precious trickle has been brought,

Clear às when caught." 
The morning came. To the park of the peer The royal couple bore;

And the font was filled with the Jordan water, And the household awaited their guests before The carpeted door.

But when they went to the silk-lined cot The child was found to have died. "What's now to be done? We can disappoint not

The king and queen!" the family cried With eyes spread wide.

"Even now they approach the chestnutdrive!

The service must be read."

"Well, since we can't christen the child alive, By God we shall have to christen him dead!"

The marquis said.

Thus, breath-forsaken, a corpse was taken

To the private chapel-yea-

And the king knew not, nor the queen, God wot,

That they answered for one returned to clay At the font that day. 


\section{OLD FURNITURE}

I know not how it may be with others

Who sit amid relics of householdry

That date from the days of their mothers' mothers,

But well I know how it is with me Continually.

I see the hands of the generations

That owned each shiny familiar thing

In play on its knobs and indentations,

And with its ancient fashioning Still dallying :

Hands behind hands, growing paler and paler, As in a mirror a candle-flame Shows images of itself, each frailer As it recedes, though the eye may frame Its shape the same.

On the clock's dull dial a foggy finger, Moving to set the minutes right 


\section{OLD FURNITURE}

With tentative touches that lift and linger

In the wont of a moth on a summer night,

Creeps to my sight.

On this old viol, too, fingers are dancingAs whilom-just over the strings by the nut,

The tip of a bow receding, advancing

In airy quivers, as if it would cut The plaintive gut:

And I see a face by that box for tinder, Glowing forth in fits from the dark, And fading again, as the linten cinder Kindles to red at the flinty spark, Or goes out stark.

Well, well. It is best to be up and doing, The world has no use for one to-day Who eyes things thus - no ain pursuing! He should not continue in this stay, But sink away. 


\section{A THOUGHT IN TWO MOODS}

I saw it-pink and white-revealed

Upon the white and green;

The white and green was a daisied field,

The pink and white Ethleen.

And as I looked it seemed in kind

That difference they had none; The two fair bodiments combined As varied miens of one.

A sense that, in some mouldering year, As one they both would lie,

Made me move quickly on to her

To pass the pale thought by.

She laughed and said : "Out there, to me, You looked so weather-browned, And brown in clothes, you seemed to be Made of the dusty ground!" 


\section{THE LAST PERFORMANCE}

"I A m playing my oldest tunes," declared she, "All the old tunes I know,-

Those I learnt ever so long ago."

-Why she should think just then she'd play them

Silence cloaks like snow.

When I returned from the town at nightfall

Notes continued to pour

As when I had left two hours before:

"It's the very last time," she said in closing;

"From now I play no more."

A few morns onward found her fading,

And, as her life outflew,

I thought of her playing her tunes right through ;

And I felt she had known of what was coming,

And wondered how she knew.

1912. 


\title{
"YOU ON THE TOWER"
}

\author{
I
}

"You on the tower of my factory-

What do you see up there?

Do you see Enjoyment with wide wings

Advancing to reach me here?"

_ "Yea ; I see Enjoyment with wide wings

Advancing to reach you here."

\section{II}

"Good. Soon I'll come and ask you

To tell me again thereon.

Well, what is he doing now ? Hoi, there!" "He still is flying on."

"Ah, waiting till I have full-finished.

Good. Tell me again anon. ...

\section{III}

Hoi, Watchman! I'm here. When comes he?

Between my sweats I am chill."

- "Oh, you there, working still ? 


\section{"YOU ON THE TOWER" I 2 I}

Why, surely he reached you a time back, And took you miles from your mill?

$\mathrm{He}$ duly came in his winging,

And now he has passed out of view.

How can it be that you missed him?

He brushed you by as he flew." 


\section{THE INTERLOPER}

THERE are three folk driving in a quaint old chaise,

And the cliff-side track looks green and fair; I view them talking in quiet glee

As they drop down towards the puffins' lair

By the roughest of ways ;

But another with the three rides on, I see,

Whom I like not to be there!

No: it's not anybody you think of Next A dwelling appears by a slow sweet stream Where two sit happy and half in the dark: They read, helped out by a frail-wick'd gleam, Some rhythmic text ;

But one sits with them whom they don't mark,

One I'm wishing could not be there.

No: not whom you knew and name. And now

I discern gay diners in a mansion-place, 


\section{THE INTERLOPER}

And the guests dropping wit-pert, prim, or choice,

And the hostess's tender and laughing face, And the host's bland brow;

But I cannot help hearing a hollow voice, And I'd fain not hear it there.

No: it's not from the stranger you met once. $\mathrm{Ah}$,

Yet a goodlier scene than that succeeds;

People on a lawn-quite a crowd of them. Yes,

And they chatter and ramble as fancy leads; And they say, "Hurrah!"

To a blithe speech made; save one, unwatched,

Who ought not to be there.

Nay : it's not the pale Form your imagings raise,

That waits on us all at a destined time,

It is not the Fourth Figure the Furnace showed ;

O that it were such a shape sublime

In these latter days!

It is that under which best lives corrode; Would, would it could not be there! 


\section{LOGS ON THE HEARTH}
A MEMORY OF A SISTER

$T_{H E}$ fire advances along the log Of the tree we felled, Which bloomed and bore striped apples by the peck

Till its last hour of bearing knelled.

The fork that first my hand would reach And then my foot

In climbings upward inch by inch, lies now Sawn, sapless, darkening with soot.

Where the bark chars is where, one year,

It was pruned, and bledThen overgrew the wound. But now, at last,

Its growings all have stagnated. 


\section{LOGS ON THE HEARTH I 25}

My fellow-climber rises dim

From her chilly grave-

Just as she was, her foot near mine on the bending limb,

Laughing, her young brown hand awave

December 1915. 


\section{THE SUNSHADE}

A

Here at my feet in the hard rock's chink, Merely a naked sheaf of wires!-

Twenty years have gone with their livers and diers

Since it was silked in its white or pink.

Noonshine riddles the ribs of the sunshade, No more a screen from the weakest ray;

Nothing to tell us the hue of its dyes,

Nothing but rusty bones as it lies

In its coffin of stone, unseen till to-day.

Where is the woman who carried that sunshade

Up and down this seaside place?-

Little thumb standing against its stem,

Thoughts perhaps bent on a love-stratagem,

Softening yet more the already soft face! 


\section{THE SUNSHADE}

Is the fair woman who carried that sunshade A skeleton just as her property is, Laid in the chink that none may scan? And does she regret-if regret dust canThe vain things thought when she flourished this ?

Swanage Cliffi. 


\section{THE AGEING HOUSE}

WhEN the walls were red

That now are seen

To be overspread

With a mouldy green,

A fresh fair head

Would often lean

From the sunny casement

And scan the scene,

While blithely spoke the wind to the little sycamore tree.

But storms have raged

Those walls about,

And the head has aged

That once looked out ;

And zest is suaged

And trust is doubt,

And slow effacement

Is rife throughout,

While fiercely girds the wind at the longlimbed sycamore tree! 


\section{THE CAGED GOLDFINCH}

Within a churchyard, on a recent grave,

I saw a little cage

That jailed a goldfinch. All was silence save Its hops from stage to stage.

There was inquiry in its wistful eye, And once it tried to sing ;

Of him or her who placed it there, and why, No one knew anything. 


\section{AT MADAME TUSSAUD'S IN VICTORIAN YEARS}

"That same first fiddler who leads the orchéstra to-night

Here fiddled four decades of years ago; $\mathrm{He}$ bears the same babe-like smile of selfcentred delight,

Same trinket on watch-chain, same ring on the hand with the bow.

"But his face, if regarded, is woefully wanner, and drier,

And his once dark beard has grown straggling and gray ;

Yet a blissful existence he seems to have led with his lyre,

In a trance of his own, where no wearing or tearing had sway.

"Mid these wax figures, who nothing can do, it may seem

That to do but a little thing counts a great deal ; 


\section{AT MADAME TUSSAUD'S I3 I}

To be watched by kings, councillors, queens, may be flattering to him-

With their glass eyes longing they too could wake notes that appeal."

Ah, but he played staunchly - that fiddlerwhoever he was,

With the innocent heart and the soultouching string :

May he find the Fair Haven! For did he not smile with good cause?

Yes; gamuts that graced forty years'-flight were not a small thing! 


\section{THE BALLET}

$T_{H E Y}$ crush together-a rustling heap of flesh-

Of more than flesh, a heap of souls; and then

They part, enmesh,

And crush together again,

Like the pink petals of a too sanguine rose

Frightened shut just when it blows.

Though all alike in their tinsel livery,

And indistinguishable at a sweeping glance,

They muster, maybe,

As lives wide in irrelevance;

A world of her own has each one underneath,

Detached as a sword from its sheath.

Daughters, wives, mistresses ; honest or false, sold, bought ;

Hearts of all sizes; gay, fond, gushing, or penned,

Various in thought

Of lover, rival, friend ;

Links in a one-pulsed chain, all showing one smile,

Yet severed so many a mile! 


\section{THE FIVE STUDENTS}

The sparrow dips in his wheel-rut bath,

The sun grows passionate-eyed,

And boils the dew to smoke by the paddockpath ;

As strenuously we stride,-

Five of us; dark $\mathrm{He}$, fair $\mathrm{He}$, dark She, fair She, I,
All beating by.

The air is shaken, the high-road hot, Shadowless swoons the day,

The greens are sobered and cattle at rest; but not

We on our urgent way,-

Four of us; fair She, dark She, fair $\mathrm{He}, \mathrm{I}$, are there, But one-elsewhere.

Autumn moulds the hard fruit mellow, And forward still we press

Through moors, briar-meshed plantations, clay-pits yellow, 


\section{I34 THE FIVE STUDENTS}

As in the spring hours-yes,

Three of us: fair $\mathrm{He}$, fair She, I, as heretofore,

But-fallen one more.

The leaf drops: earthworms draw it in At night-time noiselessly,

The fingers of birch and beech are skeletonthin,

And yet on the beat are we,-

Two of us; fair She, I. But no more left to go

The track we know.

Icicles tag the church-aisle leads,

The flag-rope gibbers hoarse,

The home-bound foot-folk wrap their snow-flaked heads,

Yet I still stalk the course,-

One of us. . . Dark and fair He, dark and fair She, gone :

The rest-anon. 


\section{THE WIND'S PROPHECY}

I TRAVEL on by barren farms, And gulls glint out like silver flecks Against a cloud that speaks of wrecks, And bellies down with black alarms. I say: "Thus from my lady's arms I go ; those arms I love the best!" The wind replies from dip and rise, "Nay ; toward her arms thou journeyest."

A distant verge morosely gray Appears, while clots of flying foam Break from its muddy monochrome, And a light blinks up far away. I sigh : "My eyes now as all day Behold her ebon loops of hair!' Like bursting bonds the wind responds, "Nay, wait for tresses flashing fair !"

From tides the lofty coastlands screen Come smitings like the slam of doors, Or hammerings on hollow floors, As the swell cleaves through caves unseen. 


\section{I36 THE WIND'S PROPHECY}

Say I : "Though broad this wild terrene, Her city home is matched of none!"

From the hoarse skies the wind replies: "Thou shouldst have said her sea-bord one."

The all-prevailing clouds exclude The one quick timorous transient star; The waves outside where breakers are Huzza like a mad multitude. "Where the sun ups it, mist-imbued," I cry, "there reigns the star for me!" The wind outshrieks from points and peaks : "Here, westward, where it downs, mean ye!"

Yonder the headland, vulturine, Snores like old Skrymer in his sleep, And every chasm and every steep. Blackens as wakes each pharos-shine. "I roam, but one is safely mine," I say. "God grant she stay my own!" Low laughs the wind as if it grinned : "Thy Love is one thou'st not yet known." 


\section{DURING WIND AND RAIN}

THEY sing their dearest songs-

$\mathrm{He}$, she, all of them-yea,

Treble and tenor and bass,

And one to play ;

With the candles mooning each face. . . .

Ah, no; the years $\mathrm{O}$ !

How the sick leaves reel down in throngs!

They clear the creeping moss-

Elders and juniors-aye,

Making the pathways neat

And the garden gay ;

And they build a shady seat. . . .

$\mathrm{Ah}$, no ; the years, the years;

See, the webbed white storm-birds wing across.

They are blithely breakfasting all--

Men and maidens-yea,

Under the summer tree,

With a glimpse of the bay,

While pet fowl come to the knee. . . . 
I 38 DURING WIND AND RAIN

Ah, no ; the years $O$ !

And the rotten rose is ript from the wall.

They change to a high new house,

$\mathrm{He}$, she, all of them-aye.

Clocks and carpets and chairs

On the lawn all day,

And brightest things that are theirs. . . .

Ah, no; the years, the years;

Down their chiselled names the rain-drop ploughs. 


\section{HE PREFERS HER EARTHLY}

THIs after-sunset is a sight for seeing, Cliff-heads of craggy cloud surrounding it. -And dwell you in that glory-show?

You may; for there are strange strange things in being, Stranger than I know.

Yet if that chasm of splendour claim your presence

Which glows between the ash cloud and the dun,

How changed must be your mortal mould! Changed to a firmament-riding earthless essence

From what you were of old :

All too unlike the fond and fragile creature Then known to me. . . W Well, shall I say it plain?

I would not have you thus and there, But still would grieve on, missing you, still feature You as the one you were. 


\section{THE DOLLS}

"W heneVer you dress me dolls, mammy, Why do you dress them so,

And make them gallant soldiers,

When never a one I know;

And not as gentle ladies

With frills and frocks and curls,

As people dress the dollies

Of other little girls?"

Ah-why did she not answer :-

“Because your mammy's heed

Is always gallant soldiers,

As well may be, indeed.

One of them was your daddy,

His name I must not tell ;

He's not the dad who lives here,

But one I love too well." 


\section{MOLLY GONE}

No more summer for Molly and me ;

There is snow on the tree,

And the blackbirds plump large as the rooks are, almost,

And the water is hard

Where they used to dip bills at the dawn ere her figure was lost

To these coasts, now my prison closebarred.

No more planting by Molly and me

Where the beds used to be

Of sweet-william; no training the clambering rose

By the framework of fir

Now bowering the pathway, whereon it swings gaily and blows

As if calling commendment from her.

No more jauntings by Molly and me

To the town by the sea,

Or along over Whitesheet to Wynyard's green Gap, 


\section{Catching Montacute Crest}

To the right against Sedgmoor, and Corton-

Hill's far-distant cap, And Pilsdon and Lewsdon to west.

No more singing by Molly to me

In the evenings when she

Was in mood and in voice, and the candles were lit,

And past the porch-quoin

The rays would spring out on the laurels; and dumbledores hit

On the pane, as if wishing to join.

Where, then, is Molly, who's no more with me ?

-As I stand on this lea,

Thinking thus, there's a many-flamed star in the air,

That tosses a sign

That her glance is regarding its face from her home, so that there

Her eyes may have meetings with mine. 


\section{A BACKWARD SPRING}

ThE trees are afraid to put forth buds, And there is timidity in the grass;

The plots lie gray where gouged by spuds, And whether next week will pass

Free of sly sour winds is the fret of each bush Of barberry waiting to bloom.

Yet the snowdrop's face betrays no gloom, And the primrose pants in its heedless push, Though the myrtle asks if it's worth the fight

This year with frost and rime

To venture one more time

On delicate leaves and buttons of white

From the selfsame bough as at last year's prime,

And never to ruminate on or remember What happened to it in mid-December.

April 1917. 


\title{
LOOKING ACROSS
}

\author{
I \\ IT is dark in the sky, \\ And silence is where \\ Our laughs rang high; \\ And recall do I \\ That One is out there.
}

\section{II}

The dawn is not nigh, And the trees are bare, And the waterways sigh That a year has drawn by, And Two are out there.

\section{I I}

The wind drops to die Like the phantom of Care Too frail for a cry, And heart brings to eye That Three are out there. 


\section{LOOKING ACROSS}

\section{IV}

This Life runs dry

That once ran rare

And rosy in dye,

And fleet the days fly,

And Four are out there.

v

Tired, tired am I

Of this earthly air,

And my wraith asks: Why,

Since these calmly lie,

Are not Five out there?

December 1915. 


\section{AT A SEASIDE TOWN IN I 869}

\section{(Young Lover's Reverie)}

I WENT and stood outside myself,

Spelled the dark sky

And ship-lights nigh,

And grumbling winds that passed thereby.

Then next inside myself I looked,

And there, above

All, shone my Love,

That nothing matched the image of.

Beyond myself again I ranged;

And saw the free

Life by the sea,

And folk indifferent to me.

O 'twas a charm to draw within

Thereafter, where

But she was ; care

For one thing only, her hid there! 


\section{AT A SEASIDE TOWN}

But so it chanced, without myself

I had to look,

And then I took

More heed of what I had long forsook.

The boats, the sands, the esplanade,

The laughing crowd;

Light-hearted, loud

Greetings from some not ill-endowed;

The evening sunlit cliffs, the talk,

Hailings and halts,

The keen sea-salts,

The band, the Morgenblatter Waltz.

Still, when at night I drew inside

Forward she came,

Sad, but the same

As when I first had known her name.

Then rose a time when, as by force,

Outwardly wooed

By contacts crude,

Her image in abeyance stood. . .

At last I said : This outside life

Shall not endure;

I'll seek the pure

Thought-world, and bask in her allure. 
${ }_{14} 8$ AT A SEASIDE TOWN

Myself again I crept within,

Scanned with keen care

The temple where

She'd shone, but could not find her there.

I sought and sought. But $\mathrm{O}$ her soul

Has not since thrown

Upon my own

One beam! Yea, she is gone, is gone.

From an old note. 


\section{THE GLIMPSE}

SHE sped through the door And, following in haste, And stirred to the core, I entered hot-faced; But I could not find her, No sign was behind her. "Where is she?" I said : "Who?" they asked that sat there; " Not a soul's come in sight."

— " A maid with red hair." - "Ah." They paled. "She is dead.

People see her at night, But you are the first On whom she has burst In the keen common light."

It was ages ago,

When I was quite strong:

I have waited since,-O,

I have waited so long!

-Yea, I set me to own The house, where now lone I dwell in void rooms Booming hollow as tombs! 


\section{THE GLIMPSE}

But I never come near her, Though nightly I hear her. And my cheek has grown thin And my hair has grown gray With this waiting therein; But she still keeps away! 


\section{THE PEDESTRIAN}

\section{AN INCIDENT OF 1883}

"SIR, will you let me give you a ride?

Nox Venit, and the heath is wide."

- My phaeton-lantern shone on one

Young, fair, even fresh,

But burdened with flesh :

A leathern satchel at his side,

His breathings short, his coat undone.

'Twas as if his corpulent figure slopped

With the shake of his walking when he stopped,

And, though the night's pinch grew acute,

He wore but a thin

Wind-thridded suit,

Yet well-shaped shoes for walking in,

Artistic beaver, cane gold-topped.

"Alas, my friend," he said with a smile,

"I am daily bound to foot ten mile-

Wet, dry, or dark-before I rest. 
Six months to live

My doctors give

Me as my prospect here, at best,

Unless I vamp my sturdiest !"

His voice was that of a man refined, A man, one well could feel, of mind,

Quite winning in its musical ease ;

But in mould maligned

By some disease ;

And I asked again. But he shook his head; Then, as if more were due, he said :-

"A student was I-of Schopenhauer, Kant, Hegel,_-and the fountained bower Of the Muses, too, knew my regard:

But ah-I fear me

The grave gapes near me !... Would I could this gross sheath discard, And rise an ethereal shape, unmarred!"

How I remember him !- his short breath, His aspect, marked for early death, As he dropped into the night for ever;

One caught in his prime

Of high endeavour;

From all philosophies soon to sever Through an unconscienced trick of Time! 
“WHO'S IN THE NEXT ROOM ?"

"Who's in the next room?-who?

I seemed to see

Somebody in the dawning passing through,

Unknown to me.

"Nay: you saw nought. He passed invisibly."

"Who's in the next room?-who?

I seem to hear

Somebody muttering firm in a language new

That chills the ear."

"No: you catch not his tongue who has entered there."

"Who's in the next room?-who?

I seem to feel

His breath like a clammy draught, as if it drew

From the Polar Wheel."

"No: none who breathes at all does the door conceal." 


\section{54 "WHO'S IN NEXT ROOM ?"}

"Who's in the next room?-who?

A figure wan

With a message to one in there of something due?

Shall I know him anon?"

"Yea he; and he brought such; and you'll know him anon." 


\section{AT A COUNTRY FAIR}

A $\mathbf{r}$ a bygone Western country fair

I saw a giant led by a dwarf

With a red string like a long thin scarf;

How much he was the stronger there

The giant seemed unaware.

And then I saw that the giant was blind, And the dwarf a shrewd-eyed little thing; The giant, mild, timid, obeyed the string As if he had no independent mind,

Or will of any kind.

Wherever the dwarf decided to go At his heels the other trotted meekly,

(Perhaps-I know not-reproaching weakly) Like one Fate bade that it must be so,

Whether he wished or no.

Various sights in various climes I have seen, and more I may see yet, But that sight never shall I forget, And have thought it the sorriest of pantomimes,

If once, a hundred times! 


\section{THE MEMORIAL BRASS : I86-}

"WHY do you weep there, O sweet lady, Why do you weep before that brass?(I'm a mere student sketching the mediaeval) Is some late death lined there, alas?Your father's? ... Well, all pay the debt that paid he!"

"Young man, O must I tell!-My husband's! And under

His name I set mine, and my death!Its date left vacant till my heirs should fill it,

Stating me faithful till my last breath."

— Madam, that you are a widow wakes my wonder!"

"O wait! For last month I - remarried!

"And now I fear 'twas a deed amiss.

We've just come home. And I am sick and saddened

At what the new one will say to this; And will he think-think that I should have tarried? 


\section{THE MEMORIAL BRASS 157}

"I may add, surely, - with no wish to harm him-

That he's a temper-yes, I fear !

And when he comes to church next Sunday morning,

And sees that written ... O dear, $\mathrm{O}$ dear!"

_- "Madam, I swear your beauty will disarm him!" 


\section{HER LOVE-BIRDS}

When I looked up at my love-birds

That Sunday afternoon,

There was in their tiny tune

A dying fetch like broken words,

When I looked up at my love-birds

That Sunday afternoon.

When he, too, scanned the love-birds

On entering there that day,

'Twas as if he had nought to say

Of his long journey citywards, When he, too, scanned the love-birds,

On entering there that day.

And billed and billed the love-birds,

As 'twere in fond despair

At the stress of silence where

$\mathrm{Had}$ once been tones in tenor thirds, And billed and billed the love-birds As 'twere in fond despair. 


\section{HER LOVE-BIRDS}

$\mathrm{O}$, his speech that chilled the love-birds, And smote like death on me, As I learnt what was to be, -And knew my life was broke in sherds! $\mathrm{O}$, his speech that chilled the love-birds, And smote like death on me! 


\section{PAYING CALLS}

I WENT by footpath and by stile

Beyond where bustle ends, Strayed here a mile and there a mile And called upon some friends.

On certain ones I had not seen For years past did I call, And then on others who had been The oldest friends of all.

It was the time of midsummer When they had used to roam ; But now, though tempting was the air,

I found them all at home.

I spoke to one and other of them

By mound and stone and tree Of things we had done ere days were dim, But they spoke not to me. 


\section{THE UPPER BIRCH-LEAVES}

WAR M yellowy-green

In the blue serene,

How they skip and sway

On this autumn day!

They cannot know

What has happened below,-

That their boughs down there

Are already quite bare,

That their own will be

When a week has passed,-

For they jig as in glee

To this very last.

But no; there lies

At times in their tune

A note that cries

What at first I fear

I did not hear :

"O we remember

At each wind's hollo-

Though life holds yet-

We go hence soon,

For 'tis November;

-But that you follow

You may forget!"

M V

. 161 


\section{“IT NEVER LOOKS LIKE SUMMER"}

"IT never looks like summer here

On Beeny by the sea."

But though she saw its look as drear, Summer it seemed to me.

It never looks like summer now

$$
\text { Whatever weather's there ; }
$$

But ah, it cannot anyhow,

On Beeny or elsewhere!

Boscastle,

March 8, 1913. 


\section{EVERYTHING COMES}

" $\mathrm{T}_{\text {HE house is bleak and cold }}$

Built so new for me!

All the winds upon the wold

Search it through for me ;

No screening trees abound,

And the curious eyes around

Keep on view for me."

"My Love, I am planting trees

As a screen for you

Both from winds, and eyes that tease

And peer in for you.

Only wait till they have grown,

No such bower will be known

As I mean for you."

"Then I will bear it, Love, And will wait," she said.

-So, with years, there grew a grove.

"Skill how great!" she said.

"As you wished, Dear?"_-“ Yes, I see!

But-I'm dying; and for me

'Tis too late," she said. 


\section{THE MAN WITH A PAST}

There was merry-making

When the first dart fell

As a heralding,-

Till grinned the fully bared thing,

And froze like a spell-

Like a spell.

Innocent was she,

Innocent was I,

Too simple we!

Before us we did not see,

Nearing, aught wry-

Aught wry!

I can tell it not now,

It was long ago ;

And such things cow;

But that is why and how

Two lives were so-

Were so.

164 


\section{THE MAN WITH A PAST 165}

Yes, the years matured, And the blows were three

That time ensured

On her, which she dumbly endured;

And one on me-

One on me. 


\section{HE FEARS HIS GOOD FORTUNE}

There was a glorious time At an epoch of my prime ; Mornings beryl-bespread, And evenings golden-red ; Nothing gray:

And in my heart I said, "However this chanced to be, It is too full for me, Too rare, too rapturous, rash, Its spell must close with a crash Some day !"

The radiance went on Anon and yet anon, And sweetness fell around Like manna on the ground. "I've no claim,"

Said I, " to be thus crowned :

I am not worthy this:-

Must it not go amiss?Well ... let the end foreseen

Come duly !-I am serene."

-And it came. 


\section{HE WONDERS ABOUT HIMSELF}

No use hoping, or feeling vext, Tugged by a force above or under Like some fantocine, much I wonder What I shall find me doing next !

Shall I be rushing where bright eyes be? Shall I be suffering sorrows seven ? Shall I be watching the stars of heaven, Thinking one of them looks like thee?

Part is mine of the general Will, Cannot my share in the sum of sources Bend a digit the poise of forces, And a fair desire fulfil ?

Nov. 1893. 


\section{JUBILATE}

" THE very last time I ever was here," he said, "I saw much less of the quick than I saw of the dead."

- He was a man I had met with somewhere before,

But how or when I now could recall no more.

"The hazy mazy moonlight at one in the morning

Spread out as a sea acróss the frozen snow, Glazed to live sparkles like the great breastplate adorning

The priest of the Temple, with Urim and Thummim aglow.

"The yew-tree arms, glued hard to the stiff stark air,

Hung still in the village sky as theatre-scenes When I came by the churchyard wall, and halted there

At a shut-in sound of fiddles and tambourines. 168 
"And as I stood hearkening, dulcimers, hautboys, and shawms,

And violoncellos, and a three-stringed doublebass,

Joined in, and were intermixed with a singing of psalms ;

And I looked over at the dead men's dwellingplace.

"Through the shine of the slippery snow I now could see,

As it were through a crystal roof, a great company

Of the dead minueting in stately step underground

To the tune of the instruments I had before heard sound.

“It was 'Eden New,' and dancing they sang in a chore,

'We are out of it all!-yea, in Little-Ease cramped no more !'

And their shrouded figures pacing with joy I could see

As you see the stage from the gallery. And they had no heed of me.

"And I lifted my head quite dazed from the churchyard wall

And I doubted not that it warned I should soon have my call. 
170 JUBILATE

But-" ... Then in the ashes he emptied the dregs of his cup,

And onward he went, and the darkness swallowed him up. 


\section{HE REVISITS HIS FIRST SCHOOL}

I SHOULD not have shown in the flesh,

I ought to have gone as a ghost ;

It was awkward, unseemly almost,

Standing solidly there as when fresh,

Pink, tiny, crisp-curled,

My pinions yet furled

From the winds of the world.

After waiting so many a year

To wait longer, and go as a sprite

From the tomb at the mid of some night

Was the right, radiant way to appear ;

Not as one wanzing weak

From life's roar and reek,

His rest still to seek :

Yea, beglimpsed through the quaint quarried glass

Of green moonlight, by me greener made,

When they'd cry, perhaps, "There sits his shade 


\section{72 HE REVISITS HỊS FIRST SCHOOL}

In his olden haunt-just as he was

When in Walkingame he

Conned the grand Rule-of-Three

With the bent of a bee."

But to show in the afternoon sun, With an aspect of hollow-eyed care,

When none wished to see me come there, Was a garish thing, better undone.

Yes; wrong was the way;

But yet, let me say,

I may right it-some day. 


\section{"I THOUGHT, MY HEART"}

I тнойнт, my Heart, that you had healed Of those sore smartings of the past, And that the summers had oversealed All mark of them at last. But closely scanning in the night I saw them standing crimson-bright
Just as she made them :
Nothing could fade them ;
Yea, I can swear
That there they were-
They still were there!

Then the Vision of her who cut them came, And looking over my shoulder said, "I am sure you deal me all the blame

For those sharp smarts and red; But meet me, dearest, to-morrow night, - In the churchyard at the moon's half-height, And so strange a kiss Shall be mine, I wis, That you'll cease to know If the wounds you show Be there or no!" 


\section{FRAGMENT}

Aт last I entered a long dark gallery,

Catacomb-lined; and ranged at the side

Were the bodies of men from far and wide Who, motion past, were nevertheless not dead.

"The sense of waiting here strikes strong; Everyone's waiting, waiting, it seems to me;

What are you waiting for so long?What is to happen?" I said.

"O we are waiting for one called God," said they,

"(Though by some the Will, or Force, or Laws ;

And, vaguely, by some, the Ultimate Cause ;)

Waiting for him to see us before we are clay.

Yes ; waiting, waiting, for God to know it." ...

"To know what?" questioned I.

"To know how things have been going on earth and below it: 
It is clear he must know some day."

I thereon asked them why.

"Since he made us humble pioneers

Of himself in consciousness of Life's tears,

It needs no mighty prophecy

To tell that what he could mindlessly show His creatures, he himself will know.

"By some still close-cowled mystery We have reached feeling faster than he, But he will overtake us anon,

If the world goes on." 


\section{MIDNIGHT ON THE GREAT WESTERN}

IN the third-class seat sat the journeying boy,

And the roof-lamp's oily flame

Played down on his listless form and face, Bewrapt past knowing to what he was going, Or whence he came.

In the band of his hat the journeying boy

Had a ticket stuck; and a string Around his neck bore the key of his box, That twinkled gleams of the lamp's sad beams Like a living thing.

What past can be yours, $O$ journeying boy

Towards a world unknown, Who calmly, as if incurious quite On all at stake, can undertake This plunge alone?

Knows your soul a sphere, $\mathrm{O}$ journeying boy, Our rude realms far above, Whence with spacious vision you mark and mete

This region of sin that you find you in, But are not of ? 


\section{HONEYMOON-TIME AT AN INN}

AT the shiver of morning, a little before the false dawn,

The moon was at the window-square, Deedily brooding in deformed decay-

The curve hewn off her cheek as by an adze ;

At the shiver of morning a little before the false dawn

So the moon looked in there.

Her speechless eyeing reached across the chamber, Where lay two souls opprest,

One a white lady sighing, "Why am I sad!"

To him who sighed back, "Sad, my Love, am I!

And speechlessly the old moon conned the chamber,

And these two reft of rest.

M V

177 
While their large-pupilled vision swept the scene there,

Nought seeming imminent,

Something fell sheer, and crashed, and from the floor

Lay glittering at the pair with a shattered gaze,

While their large-pupilled vision swept the scene there,

And the many-eyed thing outleant.

With a start they saw that it was an old-time pier-glass

Which had stood on the mantel near, Its silvering blemished,-yes, as if worn away

By the eyes of the countless dead who had smirked at it

Ere these two ever knew that old-time pier-
And its vague and vacant leer.

As he looked, his bride like a moth skimmed forth, and kneeling

Quick, with quivering sighs,

Gathered the pieces under the moon's sly ray,

Unwitting as an automaton what she did ; 
Till he entreated, hasting to where she was kneeling,

"Let it stay where it lies!"

"Long years of sorrow this means!" breathed the lady

As they retired. "Alas!"

And she lifted one pale hand across her eyes.

"Don't trouble, Love ; it's nothing," the bridegroom said.

"Long years of sorrow for us!" murmured the lady,

"Or ever this evil pass!"

And the Spirits Ironic laughed behind the wainscot,

And the Spirits of Pity sighed.

"It's good," said the Spirits Ironic, " to tickle their minds

With a portent of their wedlock's aftergrinds."

And the Spirits of Pity sighed behind the wainscot,

"It's a portent we cannot abide !

"More, what shall happen to prove the truth of the portent?" 


\section{0 \\ HONEYMOON-TIME}

- "Oh ; in brief, they will fade till old, And their loves grow numbed ere death, by the cark of care."

- "But nought see we that asks for portents there?-

'Tis the lot of all." - "Well, no less true is a portent

That it fits all mortal mould." 


\title{
THE ROBIN
}

\author{
When up aloft \\ I fly and fly, \\ I see in pools \\ The shining sky, \\ And a happy bird \\ Am I, am I!
}

When I descend

Towards their brink

I stand, and look, And stoop, and drink, And bathe my wings, And chink and prink.

When winter frost Makes earth as steel

I search and search

But find no meal, And most unhappy Then I feel. 
I 82

\section{THE ROBIN}

But when it lasts, And snows still fall, I get to feel

No grief at all,

For I turn to a cold stiff

Feathery ball ! 


\section{"I ROSE AND WENT TO ROU'TOR TOWN" \\ (She, alone)}

I ROSE and went to Rou'tor Town

With gaiety and good heart,

And ardour for the start,

That morning ere the moon was down

That lit me off to Rou'tor Town

With gaiety and good heart.

When sojourn soon at Rou'tor Town

Wrote sorrows on my tace,

I strove that none should trace

The pale and gray, once pink and brown,

When sojourn soon at Rou'tor Town

Wrote sorrows on my face.

The evil wrought at Rou'tor Town

On him I'd loved so true

I cannot tell anew :

But nought can quench, but nought can drown

The evil wrought at Rou'tor Town

On him I'd loved so true! 


\section{THE NETTLES}

THis, then, is the grave of my son, Whose heart she won! And nettles grow Upon his mound; and she lives just below.

How he upbraided me, and left, And our lives were cleft, because I said She was hard, unfeeling, caring but to wed.

Well, to see this sight I have fared these miles,

And her firelight smiles from her window there,

Whom he left his mother to cherish with tender care!

It is enough. I'll turn and go;

Yes, nettles grow where lone lies he, Who spurned me for seeing what he could not see. 


\section{IN A WAITING-ROOM}

ON a morning sick as the day of doom

With the drizzling gray

Of an English May,

There were few in the railway waiting-room. About its walls were framed and varnished Pictures of liners, fly-blown, tarnished.

The table bore a Testament

For travellers' reading, if suchwise bent.

I read it on and on, And, thronging the Gospel of Saint John, Were figures-additions, multiplicationsBy some one scrawled, with sundry emendations ;

Not scoffingly designed,

But with an absent mind,-

Plainly a bagman's counts of cost, What he had profited, what lost ; And whilst I wondered if there could have been

Any particle of a soul

In that poor man at all, 
To cypher rates of wage

Upon that printed page,

There joined in the charmless scene

And stood over me and the scribbled book

(To lend the hour's mean hue

A smear of tragedy too)

A soldier and wife, with haggard look

Subdued to stone by strong endeavour ;

And then I heard

From a casual word

They were parting as they believed for ever.

But next there came

Like the eastern flame

Of some high altar, children - a pairWho laughed at the fly-blown pictures there.

' Here are the lovely ships that we, Mother, are by and by going to see!

When we get there it's 'most sure to be fine, And the band will play, and the sun will shine!"

It rained on the skylight with a din As we waited and still no train came in ; But the words of the child in the squalid room

Had spread a glory through the gloom. 


\section{THE CLOCK-WINDER}

IT is dark as a cave,

Or a vault in the nave When the iron door Is closed, and the floor Of the church relaid With trowel and spade.

But the parish-clerk Cares not for the dark As he winds in the tower At a regular hour The rheumatic clock, Whose dilatory knock You can hear when praying At the day's decaying, Or at any lone while From a pew in the aisle.

$\mathrm{Up}$, up from the ground Around and around

In the turret stair

He clambers, to where

The wheelwork is, 
With its tick, click, whizz, Reposefully measuring Each day to its end That mortal men spend In sorrowing and pleasuring Nightly thus does he climb To the trackway of Time.

Him I followed one night To this place without light, And, ere I spoke, heard Him say, word by word, At the end of his winding, The darkness unminding :-

"So I wipe out one more, My Dear, of the sore Sad days that still be, Like a drying Dead Sea, Between you and me!"

Who she was no man knew :

He had long borne him blind To all womankind ;

And was ever one who Kept his past out of view. 


\section{OLD EXCURSIONS}

"What's the good of going to Ridgeway,

Cerne, or Sydling Mill,

Or to Yell'ham Hill,

Blithely bearing Casterbridge-way

As we used to do?

She will no more climb up there,

Or be visible anywhere

In those haunts we knew."

But to-night, while walking weary,

Near me seemed her shade,

Come as 'twere to upbraid

This my mood in deeming dreary

Scenes that used to please ;

And, if she did come to me, Still solicitous, there may be

Good in going to these.

So, I'll care to roam to Ridgeway,

Cerne, or Sydling Mill,

Or to Yell'ham Hill, 
190 OLD EXCURSIONS

Blithely bearing Casterbridge-way

As we used to do,

Since her phasm may flit out there, And may greet me anywhere

In those haunts we knew.

April 1913. 


\section{THE MASKED FACE}

I found me in a great surging space,

At either end a door,

And I said : "What is this giddying place,

With no firm-fixed floor,

That I knew not of before?"

"It is Life," said a mask-clad face.

I asked : "But how do I come here,

Who never wished to come ;

Can the light and air be made more clear,

The floor more quietsome,

And the doors set wide? They numb

Fast-locked, and fill with fear."

The mask put on a bleak smile then, And said, " $O$ vassal-wight,

There once complained a goosequill pen

To the scribe of the Infinite

Of the words it had to write

Because they were past its ken." 


\section{IN A WHISPERING GALLERY}

That whisper takes the voice

Of a Spirit, speaking to me,

Close, but invisible,

And throws me under a spell

At the kindling vision it brings;

And for a moment I rejoice,

And believe in transcendent things

That would mould from this muddy earth

A spot for the splendid birth

Of everlasting lives,

Whereto no night arrives ;

And from this gaunt gallery

A tabernacle of worth

On this drab-aired afternoon,

When you can barely see

Across its hazed lacune

If opposite aught there be

Of fleshed humanity

Wherewith I may commune;

Or if the voice so near

Be a soul's voice floating here. 


\section{THE SOMETHING THAT SAVED HIM}

IT was when

Whirls of thick waters laved me

Again and again,

That something arose and saved me;

Yea, it was then.

In that day

Unseeing the azure went 1

On my way,

And to white winter bent I,

Knowing no May.

Reft of renown,

Under the night clouds beating

Up and down,

In my needfulness greeting

Cit and clown.

Long there had been

Much of a murky colour

In the scene,

Dull prospects meeting duller;

Nought between.

M V

193

o 
Last, there loomed

A closing-in blind alley,

Though there boomed

A feeble summons to rally

Where it gloomed.

The clock rang;

The hour brought a hand to deliver;

I upsprang,

And looked back at den, ditch and river,

And sang. 


\section{THE ENEMY'S PORTRAIT}

He saw the portrait of his enemy, offered At auction in a street he journeyed nigh, That enemy, now late dead, who in his lifetime

Had injured deeply him the passer-by. " To get that picture, pleased be God, I'll try, And utterly destroy it ; and no more Shall be inflicted on man's mortal eye A countenance so sinister and sore!"

And so he bought the painting. Driving homeward,

"The frame will come in useful," he declared, "The rest is fuel." On his arrival, weary, Asked what he bore with him, and how he fared,

He said he had bid for a picture, though he cared

For the frame only: on the morrow he Would burn the canvas, which could well be spared,

Seeing that it portrayed his enemy 


\section{I96 THE ENEMY'S PORTRAIT}

Next day some other duty found him busy:

The foe was laid his face against the wall ;

But on the next he set himself to loosen

The straining-strips. And then a casual call

Prevented his proceeding therewithal ;

And thus the picture waited, day by day,

Its owner's pleasure, like a wretched thrall,

Until a month and more had slipped away.

And then upon a morn he found it shifted, Hung in a corner by a servitor.

"Why did you take on you to hang that picture?

You know it was the frame I bought it for." "It stood in the way of every visitor,

And I just hitched it there."- "Well, it must go :

I don't commemorate men whom I abhor. Remind me 'tis to do. The frame I'll stow."

But things become forgotten. In the shadow Of the dark corner hung it by its string, And there it stayed - once noticed by its owner,

Who said, "Ah me-I must destroy that thing!"

But when he died, there, none remembering, It hung, till moved to prominence, as one sees ;

And comers pause and say, examining, "I thought they were the bitterest enemies?" 


\section{IMAGININGS}

SHE saw herself a lady

With fifty frocks in wear, And rolling wheels, and rooms the best,

And faithful maidens' care,

And open lawns and shady

For weathers warm or drear.

She found herself a striver,

All liberal gifts debarred,

With days of gloom, and movements stressed,

And early visions marred,

And got no man to wive her

But one whose lot was hard.

Yet in the moony night-time

She steals to stile and lea

During his heavy slumberous rest

When homecome wearily,

And dreams of some blest bright-time

She knows can never be. 


\section{ON THE DOORSTEP}

THE rain imprinted the step's wet shine With target-circles that quivered and crossed As I was leaving this porch of mine ; When from within there swelled and paused

A song's sweet note ; And back I turned, and thought, "Here I'll abide."

The step shines wet beneath the rain, Which prints its circles as heretofore; I watch them from the porch again, But no song-notes within the door

Now call to me

To shun the dripping lea And forth I stride.

Jan. 1914 . 


\section{SIGNS AND TOKENS}

$S_{A I D}$ the red-cloaked crone In a whispered moan :

"The dead man was limp When laid in his chest;

Yea, limp ; and why

But to signify

That the grave will crimp

Ere next year's sun

Yet another one

Of those in that house-

It may be the best-

For its endless drowse!"

Said the brown-shawled dame To confirm the same :

"And the slothful flies

On the rotting fruit

Have been seen to wear

While crawling there

Crape scarves, by eyes

That were quick and acute; 
As did those that had pitched

On the cows by the pails, And with flaps of their tails

Were far away switched."

Said the third in plaid, Each word being weighed :

"And trotting does

In the park, in the lane,

And just outside

The shuttered pane,

Have also been heard-

Quick feet as light

As the feet of a sprite-

And the wise mind knows

What things may betide

When such has occurred."

Cried the black-craped fourth, Cold faced as the north :

" $\mathrm{O}$, though giving such Some head-room, I smile At your falterings

When noting those things

Round your domicile!

For what, what can touch

One whom, riven of all

That makes life gay,

No hints can appal

Of more takings away!" 


\section{PATHS OF FORMER TIME}

No ; no ;

It must not be so :

They are the ways we do not go.

\section{Still chew}

The kine, and moo

In the meadows we used to wander through ;

\section{Still purl}

The rivulets and curl

Towards the weirs with a musical swirl ;

\section{Haymakers}

\section{As in former years}

Rake rolls into heaps that the pitchfork rears ;

\section{Wheels crack}

On the turfy track

The waggon pursues with its toppling pack. 201 


\section{PATHS OF FORMER TIME}

"Why then shun-

Since summer's not done-

All this because of the lack of one?"

\section{Had you been \\ Sharer of that scene}

You would not ask while it bites in keen

Why it is so

We can no more go

By the summer paths we used to know!

1913. 


\section{THE CLOCK OF THE YEARS \\ "A spirit passed before my face; the hair of my flesh stood up."}

And the Spirit said,

"I can make the clock of the years go backward,

But am loth to stop it where you will."

And I cried, "Agreed

To that. Proceed :

It's better than dead!"

He answered, "Peace";

And called her up-as last before me ;

Then younger, younger she freshed, to the year

I first had known

Her woman-grown,

And I cried, "Cease !-

"Thus far is good--

It is enough-let her stay thus always!" But alas for me. He shook his head: 


\section{THE CLOCK OF THE YEARS}

No stop was there ;

And she waned child-fair,

And to babyhood.

Still less in mien

To my great sorrow became she slowly, And smalled till she was nought at all

In his checkless griff;

And it was as if

She had never been.

“Better," I plained,

"She were dead as before! The memory of her

Had lived in me ; but it cannot now!"

And coldly his voice :

"It was your choice

To mar the ordained."

1916. 


\section{AT THE PIANO}

A woman was playing,

A man looking on ; And the mould of her face, And her neck, and her hair, Which the rays fell upon Of the two candles there,

Sent him mentally straying

In some fancy-place

Where pain had no trace.

A cowled Apparition

Came pushing between; And her notes seemed to sigh, And the lights to burn pale, As a spell numbed the scene. But the maid saw no bale, And the man no monition; And Time laughed awry, And the Phantom hid nigh. 


\section{THE SHADOW ON THE STONE}

I went by the Druid stone

That broods in the garden white and lone, And I stopped and looked at the shifting shadows

That at some moments there are thrown

From the tree hard by with a rhythmic swing,

And they shaped in my imagining

To the shade that a well-known head and shoulders

Threw there when she was gardening.

I thought her behind my back, Yea, her I long had learned to lack, And I said: "I am sure you are standing behind me,

Though how do you get into this old track?"

And there was no sound but the fall of a leaf

As a sad response; and to keep down grief

I would not turn my head to discover

That there was nothing in my belief. 


\section{SHADOW ON THE STONE 207}

\section{Yet I wanted to look and see}

That nobody stood at the back of me ;

But I thought once more: "Nay, I'll not unvision

A shape which, somehow, there may be."

So I went on softly from the glade, And left her behind me throwing her shade, As she were indeed an apparition-

My head unturned lest my dream should fade.

Begun 1913 : finished 1916. 


\title{
IN THE GARDEN
}

\author{
(M. H.)
}

$\mathrm{W}_{\mathrm{E}}$ waited for the sun

To break its cloudy prison

(For day was not yet done,

And night still unbegun)

Leaning by the dial.

After many a trial-

We all silent there-

It burst as new-arisen,

Shading its finger where

Time travelled at that minute.

Little saw we in it,

But this much I know,

Of lookers on that shade,

Her towards whom it made

Soonest had to go.

1915. 


\section{THE TREE AND THE LADY}

I HAVE done all I could

For that lady I knew! Through the heats I have shaded her,

Drawn to her songsters when summer has jaded her,

Home from the heath or the wood.

At the mirth-time of May,

When my shadow first lured her, I'd donned my new bravery

Of greenth : 'twas my all. Now I shiver in slavery,

Icicles grieving me gray.

Plumed to every twig's end

I could tempt her chair under me. Much did I treasure her

During those days she had nothing to pleasure her ;

Mutely she used me as friend.

M V

209

$\mathbf{P}$ 


\section{THE TREE AND THE LADY}

I'm a skeleton now, And she's gone, craving warmth. The rime sticks like a skin to me ; Through me Arcturus peers; Nor'lights shoot into me ;

Gone is she, scorning my bough! 


\section{AN UPBRAIDING}

Now I am dead you sing to me

The songs we used to know, But while I lived you had no wish Or care for doing so.

Now I am dead you come to me In the moonlight, comfortless; Ah, what would I have given alive To win such tenderness!

When you are dead, and stand to me Not differenced, as now, But like again, will you be cold As when we lived, or how? 


\section{THE YOUNG GLASS-STAINER}

“These Gothic windows, how they wear me out

With cusp and foil, and nothing straight or square,

Crude colours, leaden borders roundabout, And fitting in Peter here, and Matthew there!

"What a vocation! Here do I draw now The abnormal, loving the Hellenic norm ; Martha I paint, and dream of Hera's brow, Mary, and think of Aphrodite's form."

Nov. 1893. 


\section{LOOKING AT A PICTURE ON AN ANNIVERSARY}

But don't you know it, my dear, Don't you know it,

That this day of the year

(What rainbow-rays embow it !)

We met, strangers confessed,

But parted-blest?

Though at this query, my dear,

There in your frame

Unmoved you still appear,

You must be thinking the same,

But keep that look demure

Just to allure.

And now at length a trace

I surely vision

Upon that wistful face

Of old-time recognition,

Smiling forth, "Yes, as you say,

It is the day." 
214 LOOKING AT A PICTURE

For this one phase of you

Now left on earth

This great date must endue

With pulsings of rebirth ?-

I see them vitalize

Those two deep eyes!

But if this face I con

Does not declare

Consciousness living on

Still in it, little I care

To live myself, my dear,

Lone-labouring here!

Spring 1913. 


\section{THE CHOIRMASTER'S BURIAL}

$\mathrm{HE}$ often would ask us

That, when he died,

After playing so many

To their last rest,

If out of us any

Should here abide,

And it would not task us,

We would with our lutes

Play over him

By his grave-brim

The psalm he liked best-

The one whose sense suits

"Mount Ephraim"-

And perhaps we should seem

To him, in Death's dream,

Like the seraphim.

As soon as I knew

That his spirit was gone

I thought this his due,

And spoke thereupon. 
"I think," said the vicar, "A read service quicker Than viols out-of-doors In these frosts and hoars. That old-fashioned way Requires a fine day, And it seems to me It had better not be."

Hence, that afternoon, Though never knew he That his wish could not be, To get through it faster They buried the master Without any tune.

But 'twas said that, when At the dead of next night The vicar looked out, There struck on his ken Thronged roundabout, Where the frost was graying The headstoned grass, A band all in white Like the saints in church-glass, Singing and playing The ancient stave By the choirmaster's grave.

Such the tenor man told When he had grown old. 


\section{THE MAN WHO FORGOT}

At a lonely cross where bye-roads met

I sat upon a gate;

I saw the sun decline and set, And still was fain to wait.

A trotting boy passed up the way And roused me from my thought;

I called to him, and showed where lay A spot I shyly sought.

"A summer-house fair stands hidden where You see the moonlight thrown;

Go, tell me if within it there

A lady sits alone."

He half demurred, but took the track, And silence held the scene;

I saw his figure rambling back;

I asked him if he had been. 


\section{I8 THE MAN WHO FORGOT}

"I went just where you said, but found No summer-house was there :

Beyond the slope 'tis all bare ground; Nothing stands anywhere.

"A man asked what my brains were worth; The house, he said, grew rotten, And was pulled down before my birth, And is almost forgotten!"

My right mind woke, and I stood dumb; Forty years' frost and flower Had fleeted since I'd used to come To meet her in that bower. 


\section{WHILE DRAWING IN A CHURCH- YARD}

"IT is sad that so many of worth, Still in the flesh," soughed the yew, "Misjudge their lot whom kindly earth Secludes from view.

"They ride their diurnal round Each day-span's sum of hours In peerless ease, without jolt or bound Or ache like ours.

"If the living could but hear

What is heard by my roots as they creep Round the restful flock, and the things said there,

No one would weep."

" 'Now set among the wise,' They say: 'Enlarged in scope, That no god trumpet us to rise We truly hope.' 
220 IN A CHURCHYARD

I listened to his strange tale

In the mood that stillness brings,

And I grew to accept as the day wore pale

That show of things. 


\section{"FOR LIFE I HAD NEVER CARED GREATLY"}

For Life I had never cared greatly, As worth a man's while; Peradventures unsought,

Peradventures that finished in nought, Had kept me from youth and through manhood till lately

Unwon by its style.

In earliest years-why I know not-

I viewed it askance ;

Conditions of doubt,

Conditions that leaked slowly out,

May haply have bent me to stand and to show not

Much zest for its dance.

With symphonies soft and sweet colour It courted nie then, Till evasions seemed wrong, 
Till evasions gave in to its song, And I warmed, until living aloofly loomed duller

Than life among men.

Anew I found nought to set eyes on,

When, lifting its hand,

It uncloaked a star,

Uncloaked it from fog-damps afar,

And showed its beams burning from pole to horizon

As bright as a brand.

And so, the rough highway forgetting,

I pace hill and dale

Regarding the sky,

Regarding the vision on high,

And thus re-illumed have no humour for letting.

My pilgrimage fail. 


\section{POEMS OF WAR AND PATRIOTISM}





\section{HIS COUNTRY}

I JOUR NEYED from my native spot Across the south sea shine, And found that people in hall and cot Laboured and suffered each his lot Even as I did mine.

Thus noting them in meads and marts It did not seem to me

That my dear country with its hearts, Minds, yearnings, worse and better parts Had ended with the sea.

I further and further went anon, As such I still surveyed, And further yet-yea, on and on,

He travels southward, and looks around ; and cannot discover the boundary of his native country ;

And all the men I looked upon

Had heart-strings fellow-made.

I traced the whole terrestrial round,

Homing the other side ;

Then said I, "What is there to bound

or where his duties to

his fellowcreatures end ; My denizenship? It seems I have found

Its scope to be world-wide."

M V

225
Q 
I asked me: "Whom have I to fight, And whom have I to dare,

And whom to weaken, crush, and blight?

My country seems to have kept in sight On my way everywhere."

1913. 


\section{ENGLAND TO GERMANY IN I9I4}

"O England, may God punish thee!"

-Is it that Teuton genius flowers

Only to breathe malignity

Upon its friend of earlier hours?

-We have eaten your bread, you have eaten ours,

We have loved your burgs, your pines' green moan,

Fair Rhine-stream, and its storied towers ;

Your shining souls of deathless dowers

Have won us as they were our own :

We have nursed no dreams to shed your blood,

We have matched your might not rancorously,

Save a flushed few whose blatant mood

You heard and marked as well as we

To tongue not in their country's key;

But yet you cry with face aflame,

"O England, may God punish thee !"

And foul in onward history,

And present sight, your ancient name.

Autumn $19 ! 4$. 


\section{ON THE BELGIAN EXPATRIATION}

I DREAMT that people from the Land of Chimes

Arrived one autumn morning with their bells, To hoist them on the towers and citadels Of my own country, that the musical rhymes

Rung by them into space at meted times Amid the market's daily stir and stress, And the night's empty star-lit silentness, Might solace souls of this and kindred climes.

Then I awoke; and lo, before me stood The visioned ones, but pale and full of fear ; From Bruges they came, and Antwerp, and Ostend,

No carillons in their train. Foes of mad mood

Had shattered these to shards amid the gear Of ravaged roof, and smouldering gable-end.

October 18, 1914. 


\section{AN APPEAL TO AMERICA ON BEHALF OF THE BELGIAN DESTITUTE}

Seven millions stand

Emaciate, in that ancient Delta-land :-

We here, full-charged with our own maimed and dead,

And coiled in throbbing conflicts slow and sore,

Can poorly soothe these ails unmerited Of souls forlorn upon the facing shore ! Where naked, gaunt, in endless band on band Seven millions stand.

No man can say

To your great country that, with scant delay, You must, perforce, ease them in their loud need :

We know that nearer first your duty lies; But-is it much to ask that you let plead Your lovingkindness with you-wooingwise-

Albeit that aught you owe, and must repay,

No man can say?

December 1914. 


\section{THE PITY OF IT}

I wALKED in loamy Wessex lanes, afar

From rail-track and from highway, and I heard

In field and farmstead many an ancient word Of local lineage like " Thu bist," "Er war,"

"Ich woll," "Er sholl," and by-talk similar, Nigh as they speak who in this month's moon gird

At England's very loins, thereunto spurred By gangs whose glory threats and slaughters are.

Then seemed a Heart crying : "Whosoever they be

At root and bottom of this, who flung this flame

Between kin folk kin tongued even as are we,

"Sinister, ugly, lurid, be their fame ;

May their familiars grow to shun their name, And their breed perish everlastingly."

April 1915. 


\section{IN TIME OF WARS AND TUMULTS}

"Would that I'd not drawn breath here!" some one said,

"To stalk upon this stage of evil deeds, Where purposelessly month by month proceeds A play so sorely shaped and blood-bespread."

Yet had his spark not quickened, but lain dead To the gross spectacles of this our day, And never put on the proffered cloak of clay, He had but known not things now manifested;

Life would have swirled the same. Morns would have dawned

On the uprooting by the night-gun's stroke Of what the yester noonshine brought to flower ;

Brown martial brows in dying throes have wanned

Despite his absence; hearts no fewer been broke

By Empery's insatiate lust of power.

1915. 


\section{IN TIME OF "THE BREAKING OF NATIONS"}

I

ONLY a man harrowing clods

In a slow silent walk

With an old horse that stumbles and nods

Half asleep as they stalk.

II

Only thin smoke without flame From the heaps of couch-grass; Yet this will go onward the same Though Dynasties pass.

III

Yonder a maid and her wight

Come whispering by :

War's annals will cloud into night

Ere their story die.

1915.

1 Jer. li. 20. 


\section{CRY OF THE HOMELESS}

AFTER THE PRUSSIAN INVASION OF BELGIUM

"INSTigator of the ruin-

Whichsoever thou mayst be

Of the masterful of Europe

That contrived our misery-

Hear the wormwood-worded greeting

From each city, shore, and lea

Of thy victims :

"Conqueror, all hail to thee!"

"Yea : 'All hail!' we grimly shout thee

That wast author, fount, and head

Of these wounds, whoever proven

When our times are throughly read.

' May thy loved be slighted, blighted,

And forsaken,' be it said

By thy victims,

'And thy children beg their bread!'

"Nay : a richer malediction!-

Rather let this thing befall 


\section{CRY OF THE HOMELESS}

In time's hurling and unfurling

On the night when comes thy call;

That compassion dew thy pillow

And bedrench thy senses all

For thy victims,

Till death dark thee with his pall."

August 1915. 


\section{BEFORE MARCHING AND AFTER}

$$
\text { (In Memoriam F.W.G.) }
$$

ORion swung southward aslant Where the starved Egdon pine-trees had thinned,

The Pleiads aloft seemed to pant

With the heather that twitched in the wind ;

But he looked on indifferent to sights such as these,

Unswayed by love, friendship, home joy or home sorrow,

And wondered to what he would march on the morrow.

The crazed household-clock with its whirr

Rang midnight within as he stood, He heard the low sighing of her Who had striven from his birth for his good ; 
236 MARCHING AND AFTER

But he still only asked the spring starlight, the breeze,

What great thing or small thing his history would borrow

From that Game with Death he would play on the morrow.

When the heath wore the robe of late summer,

And the fuchsia-bells, hot in the sun,

Hung red by the door, a quick comer

- Brought tidings that marching was done

For him who had joined in that game overseas

Where Death stood to win, though his name was to borrow

A brightness therefrom not to fade on the morrow.

September 1915. 


\section{"OFTEN WHEN WARRING"}

Often when warring for he wist not what, An enemy-soldier, passing by one weak, Has tendered water, wiped the burning cheek, And cooled the lips so black and clammed and hot ;

Then gone his way, and maybe quite forgot The deed of grace amid the roar and reek; Yet larger vision than loud arms bespeak He there has reached, although he has known it not.

For natural mindsight, triumphing in the act Over the throes of artificial rage,

Has thuswise muffled victory's peal of pride, Rended to ribands policy's specious page That deals but with evasion, code, and pact, And war's apology wholly stultified.

1915. 


\section{THEN AND NOW}

W HEN battles were fought With a chivalrous sense of Should and Ought,

In spirit men said,

"End we quick or dead,

Honour is some reward!

Let us fight fair-for our own best or worst ;

So, Gentlemen of the Guard,

Fire first!"

In the open they stood,

Man to man in his knightlihood:

They would not deign

To profit by a stain

On the honourable rules,

Knowing that practise perfidy no man durst

Who in the heroic schools

Was nurst.

But now, behold, what

Is warfare wherein honour is not!

Rama laments

Its dead innocents : 


\section{THEN AND NOW 239}

Herod breathes: "Sly slaughter

Shall rule! Let us, by modes once called accurst,

Overhead, under water, Stab first."

1915. 


\section{A CALL TO NATIONAL SERVICE}

$U_{P}$ and be doing, all who have a hand To lift, a back to bend. It must not be In times like these that vaguely linger we To air our vaunts and hopes; and leave our land

Untended as a wild of weeds and sand. -Say, then, "I come!" and go, O women and men

Of palace, ploughshare, easel, counter, pen ; That scareless, scathless, England still may stand.

Would years but let me stir as once I stirred At many a dawn to take the forward track, And with a stride plunged on to enterprize,

I now would speed like yester wind that whirred

Through yielding pines; and serve with never a slack,

So loud for promptness all around outcries!

March 1917. 


\section{THE DEAD AND THE LIVING ONE}

THE dead woman lay in her first night's grave,

And twilight fell from the clouds' concave, And those she had asked to forgive forgave.

The woman passing came to a pause By the heaped white shapes of wreath and cross,

And looked upon where the other was.

And as she mused there thus spoke she: "Never your countenance did I see, But you've been a good good friend to me!"

Rose : plaintive voice from the sod below : "O w sman whose accents I do not know, What is it that makes you approve me so?"

"O dead one, ere my soldier went, I heard him saying, with warm intent,

-To his friend, when won by your blandishment :

M V 241 R 
" 'I would change for that lass here and now! And if I return I may break my vow To my present Love, and contrive somehow

" 'To call my own this new-found pearl, Whose eyes have the light, whose lips the curl,

I always have looked for in a girl!'

"-And this is why that by ceasing to beThough never your countenance did I seeYou prove you a good good friend to me;

"And I pray each hour for your soul's repose In gratitude for your joining those

No lover will clasp when his campaigns close."

Away she turned, when arose to her eye A martial phantom of gory dye,

That said, with a thin and far-off sigh :

"O sweetheart, neither shall I clasp you, For the foe this day has pierced me through, And sent me to where she is. Adieu !-

"And forget not when the night-wind's whine

Calls over this turf where her limbs decline, That it travels on to lament by mine." 


\section{THE DEAD AND THE LIVING 243}

There was a cry by the white-flowered mound, There was a laugh from underground, There was a deeper gloom around.

1915 


\title{
A NEW YEAR'S EVE IN WAR TIME
}

\author{
I \\ Phantasmal fears, \\ And the flap of the flame, \\ And the throb of the clock, \\ And a loosened slate, \\ And the blind night's drone, \\ Which tiredly the spectral pines intone!
}

II

And the blood in my ears

Strumming always the same,

And the gable-cock

With its fitful grate,

And myself, alone.

\section{III}

The twelfth hour nears

Hand-hid, as in shame ;

I undo the lock,

And listen, and wait

For the Young Unknown. 
NEW YEAR'S EVE IN WAR $2+5$

IV

In the dark there careers-

As if Death astride came

To numb all with his knock-

A horse at mad rate

Over rut and stone.

v

No figure appears,

No call of my name,

No sound but "Tic-toc"

Without check. Past the gate

It clatters - is gone.

\section{VI}

What rider it bears

There is none to proclaim ;

And the Old Year has struck,

And, scarce animate,

The New makes moan.

\section{VII}

Maybe that " More Tears!-

More Famine and Flame-

More Severance and Shock!"

Is the order from Fate

That the Rider speeds on

To pale Europe ; and tiredly the pines intone.

$191 ;-1916$. 


\section{"I MET A MAN"}

I MET a man when night was nigh, Who said, with shining face and eye Like Moses' after Sinai :-

"I have seen the Moulder of Monarchies,

Realms, peoples, plains and hills,

Sitting upon the sunlit seas!-

And, as He sat, soliloquies

Fell from Him like an antiphonic breeze

That pricks the waves to thrills.

"Meseemed that of the maimed and dead

Mown down upon the globe,-

Their plenteous blooms of promise shed

Ere fruiting-time- - His words were said,

Sitting against the western web of red

Wrapt in His crimson robe.

"And I could catch them now and then :

- Why let these gambling clans

Of human Cockers, pit liege men

From mart and city, dale and glen,

In death-mains, but to swell and swell again

Their swollen All-Empery plans, 
" - When a mere nod (if my malign

Compeer but passive keep)

Would mend that old mistake of mine

I made with Saul, and ever consign

All Lords of War whose sanctuaries enshrine

Liberticide, to sleep?

“. With violence the lands are spread

Even as in Israel's day,

And it repenteth me I bred

Chartered armipotents lust-led

To feuds. . . Y Yea, grieves my heart, as

then I said,

To see their evil way!'

- "The utterance grew, and flapped like flame,

And further speech I feared;

But no Celestial tongued acclaim, And no huzzas from earthlings came, And the heavens mutely masked as 'twere in shame

Till daylight disappeared."

Thus ended he as night rode high-

The man of shining face and eye,

Like Moses' after Sinai.

1916. 


\section{"I LOOKED UP FROM MY WRITING "}

I LOOKED up from my writing,

And gave a start to see, As if rapt in my inditing,

The moon's full gaze on me.

Her meditative misty head Was spectral in its air, And I involuntarily said,

"What are you doing there ?"

"Oh, I've been scanning pond and hole And waterway hereabout

For the body of one with a sunken soul Who has put his life-light out.

"Did you hear his frenzied tattle? It was sorrow for his son Who is slain in brutish battle, Though he has injured none. 


\section{“FROM MY WRITING” 249}

"And now I am curious to look Into the blinkered mind

Of one who wants to write a book In a world of such a kind."

Her temper overwrought me, And I edged to shun her view, For I felt assured she thought me One who should drown him too. 

FINALE 



\section{THE COMING OF THE END}

How it came to an end !

The meeting afar from the crowd, And the love-looks and laughters unpenned The parting when much was avowed, How it came to an end!

It came to an end ; Yes, the outgazing over the stream, With the sun on each serpentine bend, Or, later, the luring moon-gleam;

It came to an end.

It came to an end,

The housebuilding, furnishing, planting,

As if there were ages to spend In welcoming, feasting, and jaunting ;

It came to an end.

It came to an end, That journey of one day a week : ("It always goes on," said a friend, "Just the same in bright weathers or bleak ;") But it came to an end. 


\section{THE COMING OF THE END}

"How will come to an end

This orbit so smoothly begun,

Unless some convulsion attend?"

I often said. "What will be done

When it comes to an end ?"

\section{Well, it came to an end}

Quite silently_stopped without jerk ;

Better close no prevision could lend;

Working out as One planned it should work

Ere it came to an end. 


\section{AFTERWARDS}

When the Present has latched its postern behind my tremulous stay,

And the May month flaps its glad green leaves like wings,

Delicate-filmed as new-spun silk, will the neighbours say,

"He was a man who used to notice such things"?

If it be in the dusk when, like an eyelid's soundless blink,

The dewfall-hawk comes crossing the shades to alight

Upon the wind-warped upland thorn, a gazer may think,

"To him this must have been a familiar sight."

If I pass during some nocturnal blackness, mothy and warm,

When the hedgehog travels furtively over the lawn, 
One may say, "He strove that such innocent creatures should come to no harm,

But he could do little for them; and now he is gone"?

If, when hearing that I have been stilled at last, they stand at the door,

Watching the full-starred heavens that winter sees,

Will this thought rise on those who will meet my face no more,

"He was one who had an eye for such mysteries"?

And will any say when my bell of quittance is heard in the gloom,

And a crossing breeze cuts a pause in its outrollings,

Till they rise again, as they were a new bell's boom,

"He hears it not now, but used to notice such things"?

THE END 
PARTICULARS OF THE VARIOUS EDITIONS

OF THE

\section{WORKS OF THOMAS HARDY}

ARE GIVEN ON THE FOLLOWING PAGES. 


\section{WESSEX EDITION OF THE WORKS OF, THOMAS HARDY \\ In 2.3 vols. 8vo. Cloth Gilt. 7s. 6d. net each. With Preface, Notes, Frontispiece and Map in each vol."}

\section{THE WESSEX NOVELS}

I.-NOVELS OF CHARACTER AND ENVIRONMENT

I. TESS OF THE D'URBERVILLES.

2. FAR FROM THE MADDING CROWD.

3. JUDE THE OBSCURE.

4. THE RETURN OF THE NATIVE.

5. THE MAYOR OF CASTERBRIDGE.

6. THE WOODLANDERS.

7. UNDER THE GREENWOOD TREE.

8. LIFE'S LITTLE IRONIES.

9. WESSEX TALES.

\section{II.-ROMANCES AND FANTASIES}

IO. A PAIR OF BLUE EYES.

11. THE TRUMPET-MAJOR.

I 2. TWO ON A TOWER.

I3. THE WELL-BELOVED.

I4. A GROUP OF NOBLE DAMES.

MACMILLAN AND CO., LTD., LONDON. 


\section{III.-NOVELS OF INGENUITY}

15. DESPERATE REMEDIES.

16. THE HAND OF ETHELBERTA.

17. A LAODICEAN.

\section{IV.-MIXED NOVELS}

18. A CHANGED MAN, THE WAITING SUPPER, AND OTHER TALES, CONCLUDING WITH THE ROMANTIC ADVENTURES OF A MILKMAID.

\section{VERSE}

I. WESSEX POEMS, AND POEMS OF THE PAST AND THE PRESENT.

2. THE DYNASTS, PARTS I. AND II.

3. THE DYNASTS, PART III., AND TIME'S LAUGHINGSTOCKS.

4. SATIRES OF CIRCUMSTANCE: Lyrics and Reveries.

5. MOMENTS OF VISION AND MISCELLANEOUS VERSES.

SELECTED POEMS. Pott 8vo. 3s. 6d. net. [Golden Treasury Series.

COMPLETE POEMS. In one vol: Crown 8 vo. MACMILLAN AND CO., LTD., LONDON. 


\section{THE WORKS OF THOMAS HARDY}

Uniform Edition. Crozun 8vo. Cloth extra. 4r. 6d. each. Pocket Edition. Printed on India Paper. Fcap. 8vo. Limp Cloth, 3s. 6d. net; Limp Lealher, 5s. net each.

TESS OF THE D'URBERVILLES.

FAR FROM THE MADDING CROWD.

THE MAYOR OF CASTERBRIDGE.

A PAIR OF BLUE EYES.

TWO ON A TOWER.

THE RETURN OF THE NATIVE.

THE WOODLANDERS.

JUDE THE OBSCURE.

THE TRUMPET-MAJOR.

THE HAND OF ETHELBERTA.

A LAODICEAN.

DESPERATE REMEDIES.

WESSEX TALES.

LIFE'S LITTLE IRONIES.

A GROUP OF NOBLE DAMES.

UNDER THE GREENWOOD TREE.

THE WELL-BELOVED.

A CHANGED MAN, ETC.

WESSEX POEMS, and Other Verses.

POEMS OF THE PAST \& THE PRESENT.

TIME'S LAUGHINGSTOCKS, and Other Verses.

SATIRES OF CIRCUMSTANCE: Lyrics and Reveries.

MOMENTS OF VISION, and Miscellaneous

Verses.

In the 4 s. Gal. edition the Poems are in two rols. In the Pocket Edition they form one comflete vol.

MACMILLAN AND CO., LTD., LONDON. 



$\begin{array}{lr}\text { PR } & \text { Hardy, Thomas } \\ 4750 & \text { Moments of vision } \\ 16 & \\ \text { cop.2 } & \end{array}$

\section{PLEASE DO NOT REMOVE} CARDS OR SLIPS FROM THIS POCKET

\section{UNIVERSITY OF TORONTO LIBRARY}




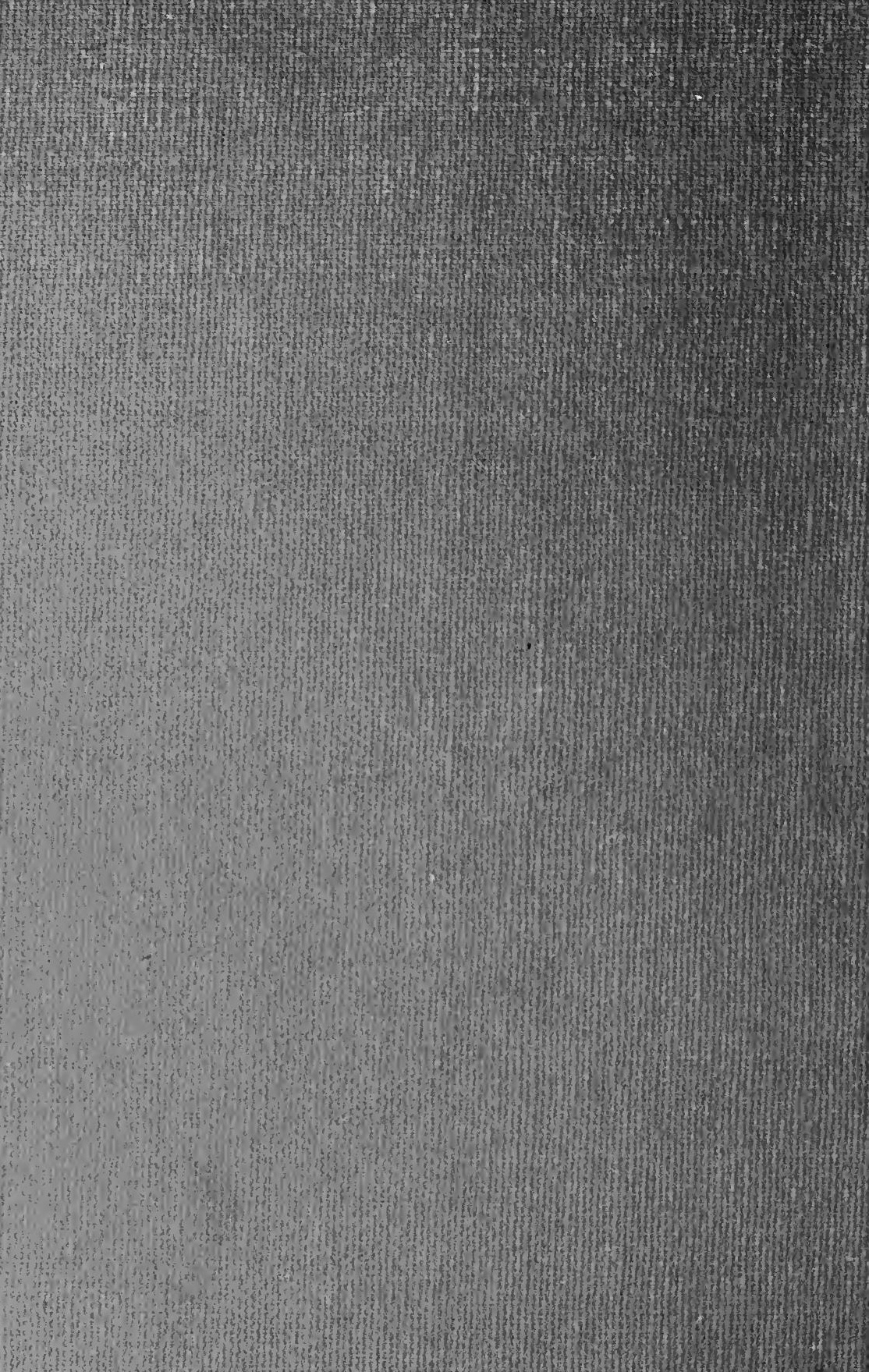

